\title{
التوظيف السايكملوجي للقطة القريبة في افلام برغمان
}

\section{م.م. صيدر فيصل كريم العسكري/ جامعة بـغداد/ كلية الفنوز الجميلة / قسم الفنوز السينمائية}

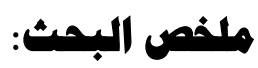

تضمن البحث الفصل الاول (الاطسار المنهجي): مشكلة البحث و التي طرحت التسـاؤل الاتي: كيف

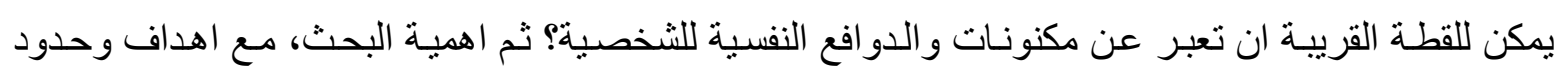

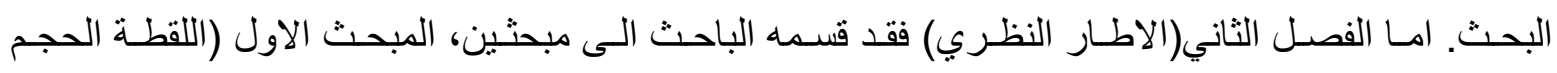
التوظيف) وفيه تم در اسـة مفهوم اللقطـة وحجو مها و المعنى الدرامي و التوظيف لكل حجم من الاحجام. امـا المبحث الثاني(الرؤيـة الفلسفية في افلام برغمـان) جـاء المبحث لتسليط الضوء على على الرؤيـا الفلسفية للمخرج

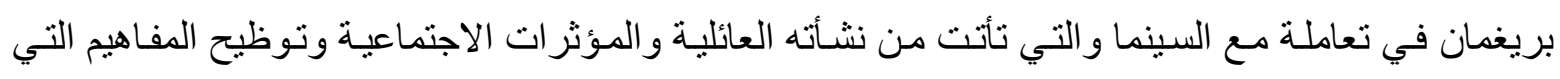
حاول التأكيد عليها و المرتبطة بمحاولة الكثف عن الدواخل النفسية للثخصية. وفخرج الباحث بمجموعة من ون المؤشرات الناتجـة الاطـار النظري والتي اعتمدها كأدوات لتحليل عينـة البحث. امـا الفصل الثالث(اجر اءات البحث) و الذي تضمن منهج البحث، مجتمع البحث، عينة البحث، اداة البحث، وحدة التحليل. ثم تم تحليل عينة البحث وهي فيلمان( القناع) و( التوت البري) وبعد تحليل عينة البحث توصل الباحث الى مجموعة من النتائج

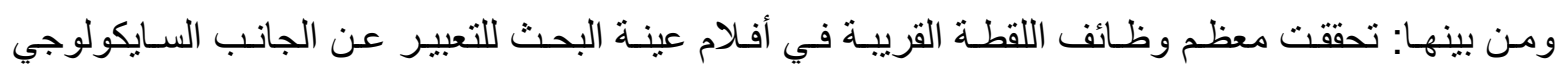
و الدر امي ضـمن سـياق الإحداث، فنجدها تعبر عن(دواخل الثخصية، ردة الفعل،الاستجابة). و انطلاقـاً مـن الاطار النظري و النتائج تم وضع الاستتناجات التي جاءت على النحو الآتي: ان دقة في قر اءة تعبيريـة اللقطـة القريبة عند بريغمان يتطلب معرفة مسبقة بأفكار وفلسفة المخرج بريغمان. واخير ا تم وضع المقترحات وختم البحث بقائمة المصادر.

أولا: مشكاة البمث:

المخرج على العـالم المصور . غير ان للقطة القريبـة خصوصية، كونها تمثل لحظة نستدعي التأمل و التركيز من قبل المتلقي الواعى، الامر الذي جعلت مشكلة البحث تتبلور لفهم للاختلافات والتحفظات في استخدامها، فمنهم من أثنـار إلى تأجيل استخدامها من اجل اللحظـات ذات العمق الدر امي الثديد فاستخدامها المفرط قد يفقدها تأثير ها الخاص، ومنهم من كان مقل جدا في استخدامها، ومنهم من يعتمدها في إيصال التأثير

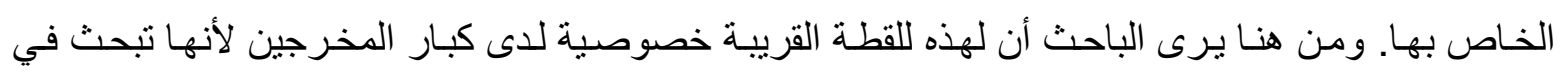

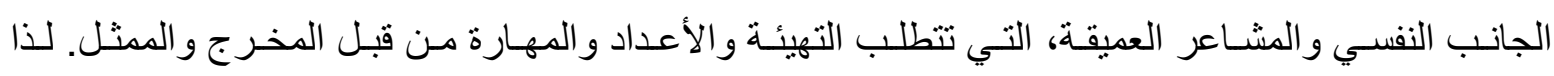
سيقتصر البحث على توظيف هذا النوع من اللقطات لدى المخرج العالمي (برغمـان) و البحث في التسـاؤل الآتي: كيف يمكن للقطة القريبة ان تعبر عن مكنونات والدو افع النفسية للشخصية؟

قانيا: اهمية البهث:

تكمن أهمية البحث في تناوله لحلقة ضيقة من عناصر لغة التعبير السينمائية اللاوهيه اللقطـة القريبـة،

التي تميز بها فن الفيلم عن باقي الفنون الأخرى في التوظيف والاستخدام للتعبير عن الجوانب السـايكولوجية 
للشخصية والكشف عن مكنوناتها الداخلية إضـافة الى وظـائف أخرى تؤديها اللقطة القريبـة حسب السياقات و البناء الفيلمي لذا نجد تنوع لغة التعبير لهذا العنصر قد تباين من مخرج إلى أخر ولكنتـا نجده عند بر غمـان

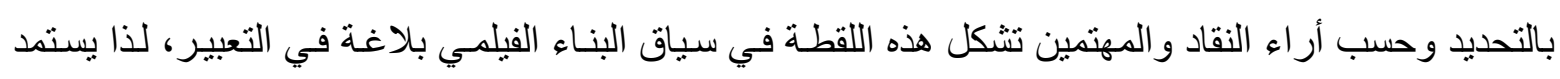

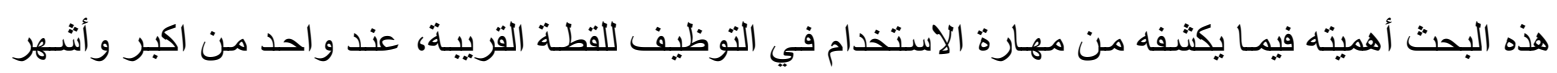
صناع الأفلام الذي يستند في رؤيته الفنية الى فلسفة الحياة إضافة الى ذلك فأن هذه النوع من الدراسـات تعدق

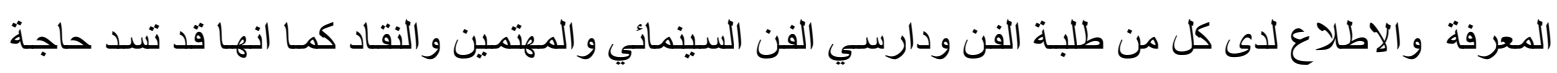

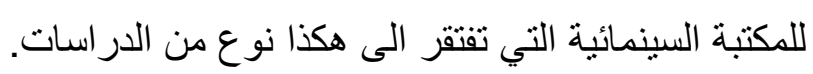

ثالثا: أهد|ف البمث:

1. التعرف على مضامين استخدم اللقطة القريبة. r. . يهدف البحث للكثف عن آليات توظيف اللقطة القريبة في أفلام المخرج (انغماربر غمان).

رابعا: مدود البمث: يتحدد البحث بدر اسة اللقطة القريية في افلام المخرج السويدي (انغماربر غمان) وذلك من خـلال عينه قصديه سيتم اختبار ها من قبل الباحث.

\section{الفصل الثـاني: (الإطار النظلري): المبمث الأول: اللقطة المجم التوظيف}

:(Shot) häll

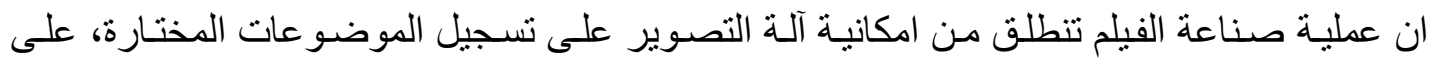

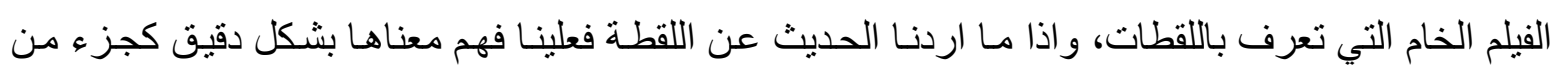
المشهد، حيث جاء في معجم الفن السينمائي بانها" وحدة اللغة السينمائية، كما ان الكلمة هي وحدة اللغة الأدبية. و اللقطة بايجاز من وجهة نظر التصوير الجزء من الفلم المطبوع بين اللحظة التي يبدأ فيها محرك الكاميرا الدوران، وبين اللحظة التي يتوقف فيها. وهي من وجهة نظر التوليف هي الجزء مـن الفلم الموجود بين

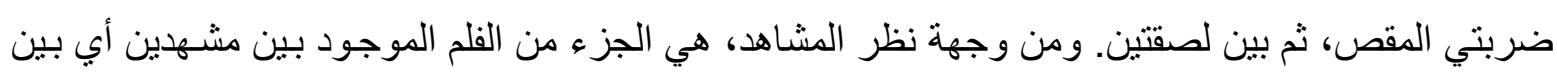

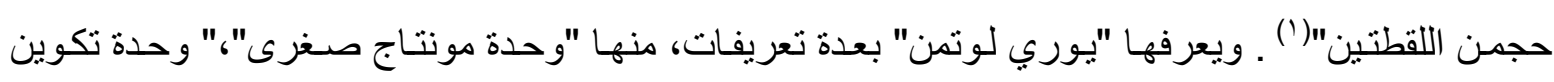

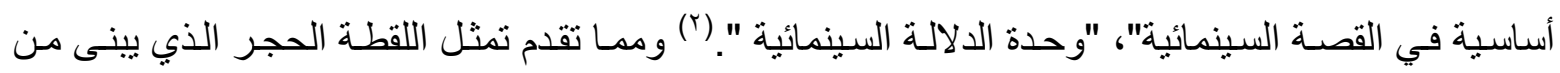
خلالة الفيلم السينمائي، و على هذا الاسـاس فـان قدرة التعبير الفلمي لابد وان تنطلق من خـلال وحدة البناء

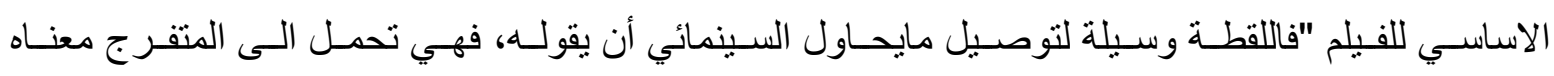
وتفسيره"()، فالعناصر المرئية بالفيلم هي أسـاس الاتصـال بين المخرج و المشـاهد، الأمر الذي يعطي اللقطـة

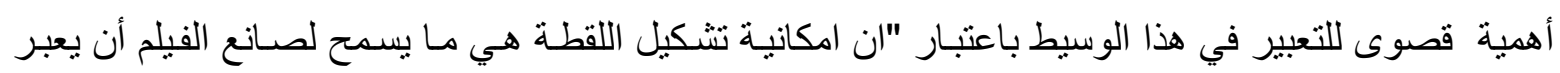

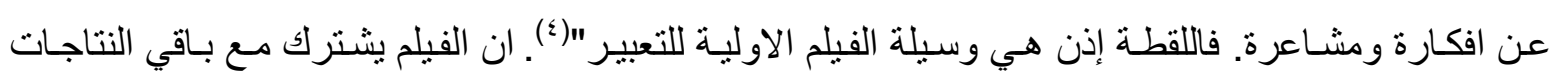
الفنية، والاشكال الادبية، بما يقدم من احداث ومواقف، غير انه تميز عنها بامتلاكـة واقع مرئي على الثانـة،

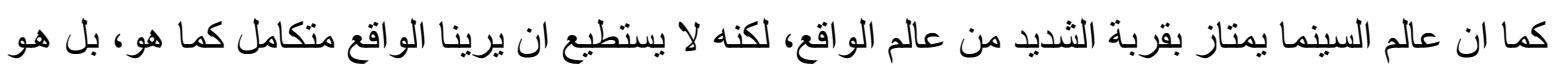


و اقع مكون من عدة أجز اء متر ابطـة لذا فان " السينما، في جميع الحالات، لا تقوم بإعادة عرض الواقع في

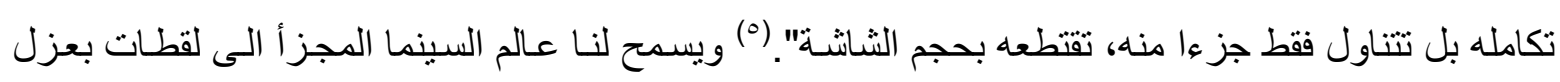

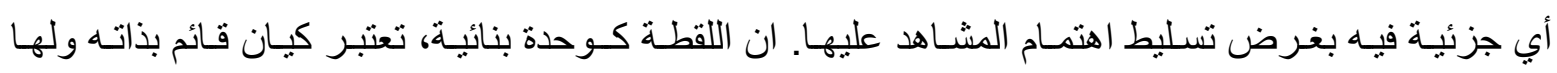
استقلاليتها بما تحوي داخل الإطلار لكنتا نجد المعنى غير ثابت عندما ترتبط بالسياق * فهنا يمكن للقطة أن تحمل معناها الخاص ويمكن إن تحيلنا إلى معنى أخر عند ارتباطها بالتي سبقتها والتي تليها فـ " يمكن لأي عنصر في اللقطة أن يتغير فجأة عندما تتصل بلقطة أخرى مساعدة على وجود الصر اع المطلوب" آنَ). فعملية

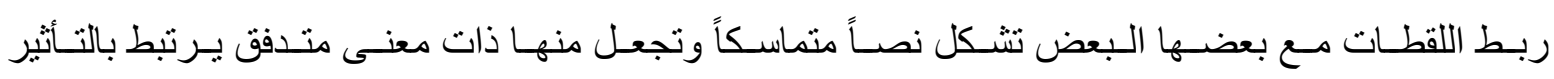

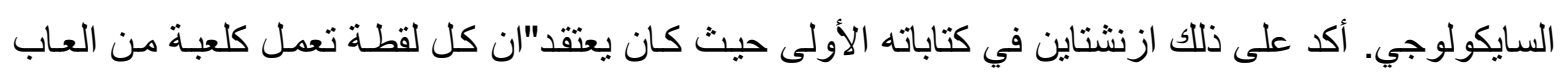

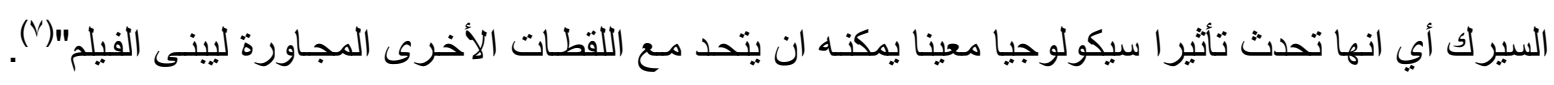

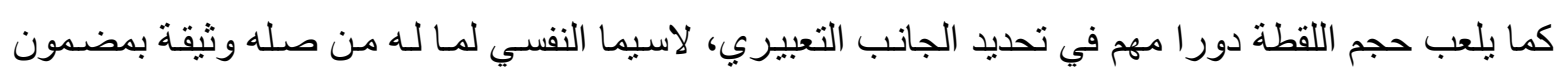

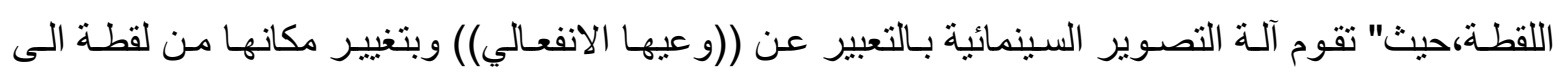
أخرى، وبتنويع الحيل السينمائية في مسافاتها ووجهات نظر ها، تنتطيع الكاميرا أن تقوم بالتعبير عن انفعالها بالأحداث"(^)، اي ان المخرج يمكن ان يتحكم بالقيمة التعبيرية للموقف، من خلال تغير المسافات بين الكاميرا

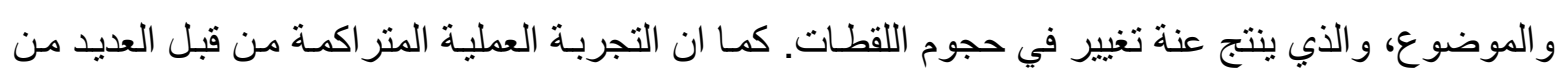

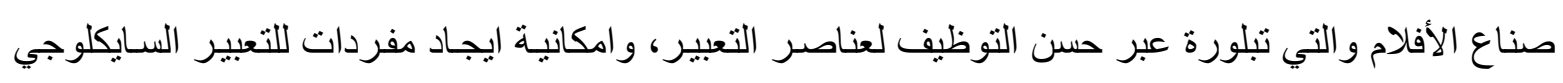

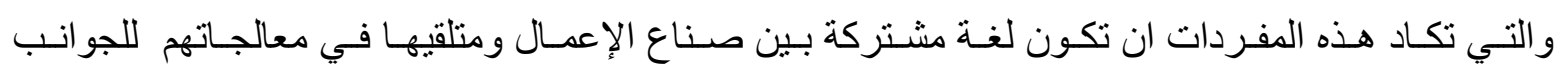
السايكلوجية للشخصية، و التي تمثل البعض منها بحركة الكامير ا عندما تتقدم نحو الثخصية لتوحي بالدخول

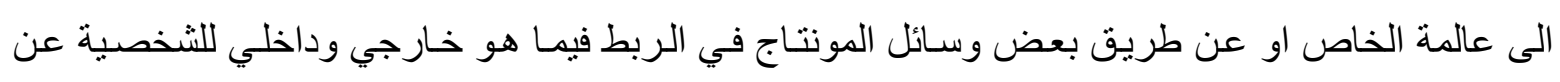
طريق التضبيب (focus) كذلك اشتغال الإضـاءة ضمن مستويات بنائية تحقق التأثير السـايكلوجي للصورة. وصو لاً الى توظيف حجم اللقطة موضو عة البحث، من حيث قربه او ابتعاده عن الثخصية فنجد ان أكثر

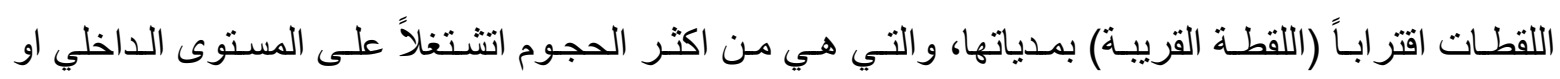

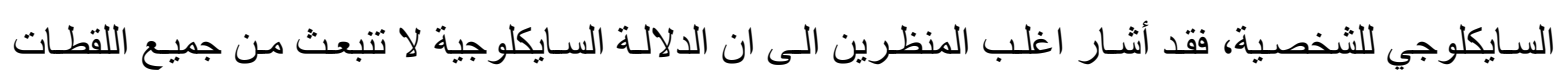

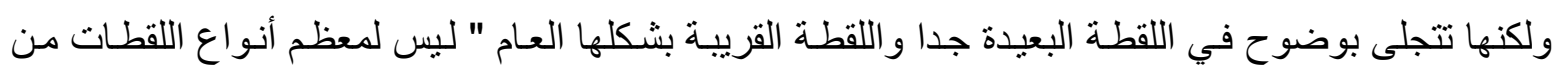
سبب غير سهولة الإدراكووضوح الرواية، فيما عدا المنظر الكبير والمنظر العام، فأن لهما في أكثر الأحيان

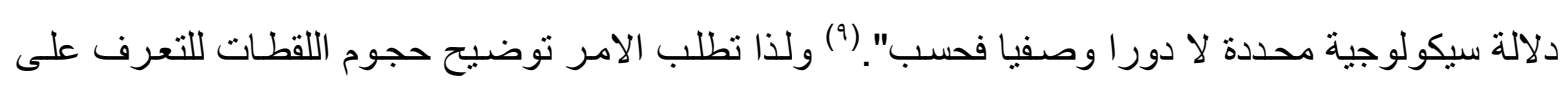
مستوى التأثير السايكلوجي، ان وجد للقطات بشكل عام وللقطة القريبة بشكل خاص؛ هناك اتفاق شبه عام بين اغلب المنظرين على تقسيم أحجام اللقطات وكما ياتي:

\section{الاقطة البعيدة جد|(Extreme Long Shot):}

و هي اللقطة التي تعرض مساحات كبيرة من الأرض، لتتسع لاحتواء مدينة أو جملة من المباني أو قرية من القرى او جزيرة في عرض البحر. وبذلك يتطلب ان يتم تصوير ها من مكان مرتفع مثل تل او برج او طائرة لذا فهي دائما لقطة خارجية، يمكن اعتبار ها ك" إطسار مكاني لتحديد اللقطات الأكبر وهي لهذا 
السبب تسمى أحيانا((اللقطات المؤسسة)) ".(·) هنالك ثلاث إغر اض لاستخدام اللقطة البعيدة جدا وكما حددها " تيرنس مارنر"*: الأول يمكنها ان توضح المكان العام لأحداث الفيلم. اما الغرض الثاني تستخدم لإلقاء نظرة

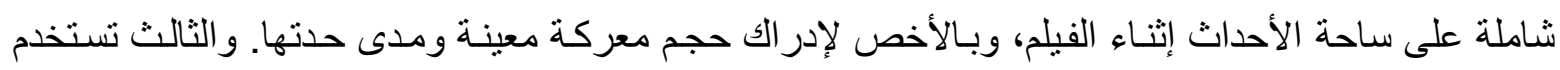
لعزل إنسان عن بيئته لوصف حالة نفسية للشخصية، أي عرض موقف فلسفي بصورة مرئية. ففي أفلام رعاة البقر يمكن لر اعي البقر الذي يعبر وحده أرض منبسطة لانهاية لها يرمز الى كفاح الفرد ضد البيئة المعادية.

\section{الاقطة البعيدة او الاقطمة العامة (Long Shot ):}

تقترب هذه اللقطة في خو اصها من اللقطات البعيدة جدا وهي من اللقطات التي يخُتلف على تحديدها بشكل دقيق لكنها " تعرض المنطقة التي يدور فيها الحدث ، وتضم مجموعة من الأشخاص بكامل أجسـامهم و الحيز المحيط بهم الكافي لحركتهم. ويسميها بعضهم ((لقطة رئيسية))". ('") ويمكن لهذه اللقطات ان توضح فئح للمشاهد، المكان بما يحتوي الساحة او المبنى والديكور ات التي يدور فيها الحدث بشكل توضح فيه العلاقة بين

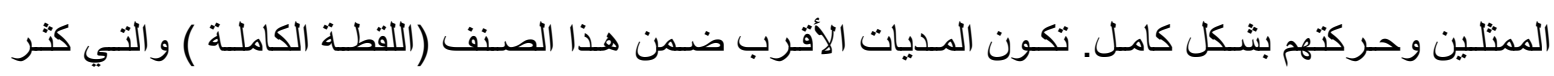
استخدامها في الأفلام الصامتة لما تتميز فيه من القرب الكافي لإظهار الملامح البارزة لوجه الممثل. لذا فضلها

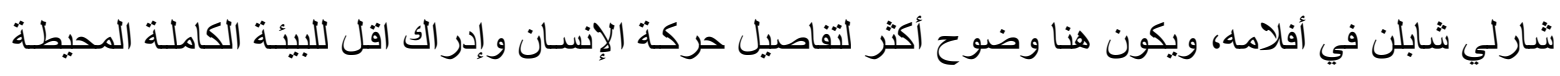

بـ

\section{الاقطة المتوسطة (Medium Shot):}

هذه اللقطة تختص بجسم الإنسان حيث بمكنها ان تضم الثخص من الركبة او الخصر حتى بعض

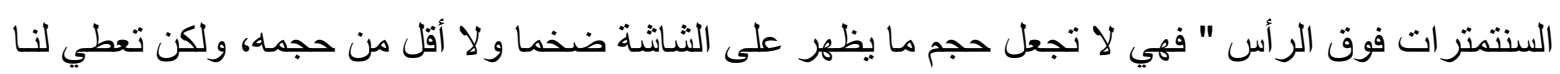

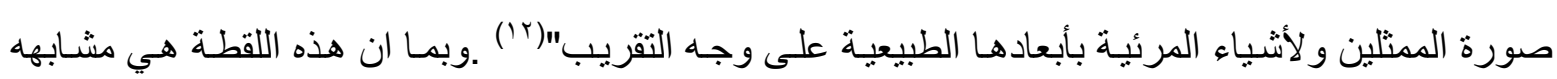

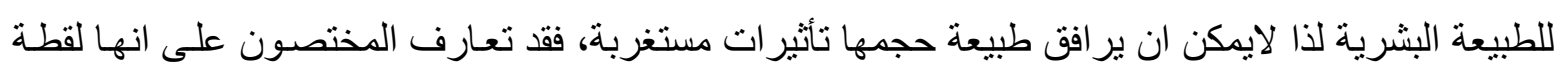

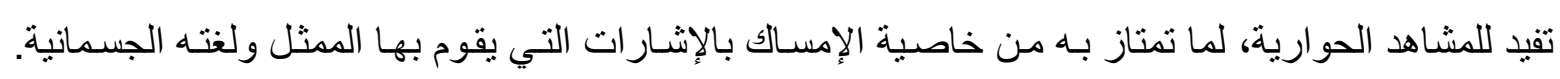
فيكون الجسم في هذه اللقطة محور الاهتمام للمشاهد، في" لهذه اللقطة فائدتها القصوى عند تطوير العلاقات بين

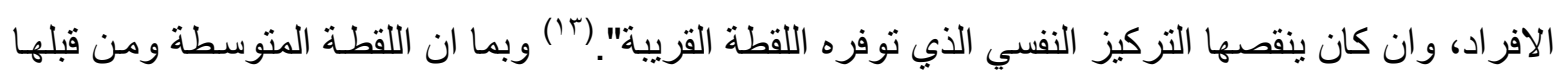

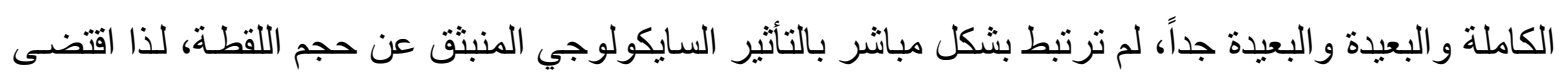

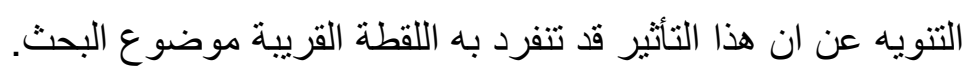

\section{اللقططة القريبة (Close up shot):}

و هي اللقطة التي تعرض لنا الجزء من الكل مثل رأس من جسم الإنسـان او الكف او القدم دون اظهار الموقع المحبط به. وبذللك يتم قطع الاشياء من عالمها المكاني، الأمر الذي يجعل تركيز الاهتمام على هنى هذه الجزء دون الكل ليعطيها القيمة الأهم لاى المتفرج من هذا نلاحظ ان"الخاصية الرئيسية للقطة القريبـة انها لهاء تتقل المتفرجين لتقربهم من الثخص او الثـيء المطلوب التركيز عليه، مـع استبعاد البيئة المحيطة بـه خـارج حدود الصورة "(؛ () ـ لتظهر لنا الثيء القليل جدا من الموقع أذا لم تستبعده بشكل تام وتركز الانتباه على جزء 


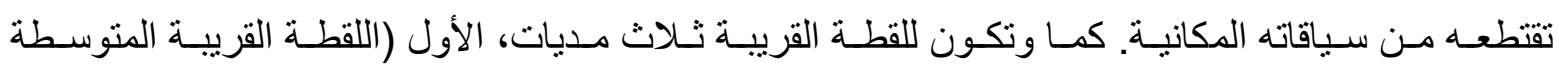
(Medium close up shot وتقيد للحوار، و لأغر اض التركيب في عملية المونتاج وتكون من الصدر و الر أس و الكتفين. الثاني (اللقطة القريبة Close up shot) التي تظهر الر أس والكتفين، لتنقل المتفرجين إلى موقع اقرب وأفضل مما تفعله القريبة المنوسطة التي سبقت. فهنا يكون التركيز أكثر على وجه الممثل، لذا

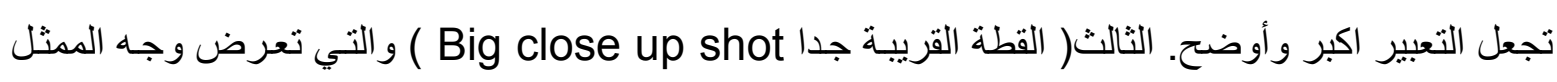
فقط، ويمكن لهذه اللقطة ان تكون مصدر ا لأكبر قدر ممكن من التركيز الدرامي، فإنها تحصر الانتباه في التفاصيل ذات الأهمية. ويتضح فيها تعبير الثخصية الى أقصى حد ممكن، كما يمكنها ان توضـح أمامنـا روح الثخصية التي يؤديها ومز اجها العام. ويمكن لهذه اللقطة ان تكثف لنا عن الكثير من الأفكار و المو اقف الذهنية التي تمر بها الثخصية. وهنالك مدا مكبر أكثر ينضوي تحت حجم اللقطة القريبـة يسمى : (اللقطة التفصيلية

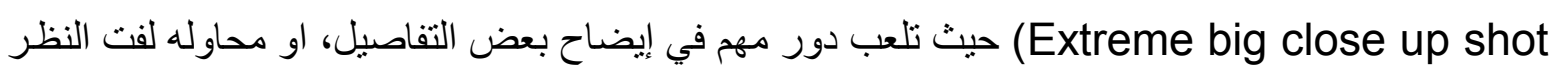
و التأكيد على جزء معين من الصورة فهو يعتبر"نسخة أضيق لكنها مكبرة جدا من اللقطة الكبيرة تستخدم

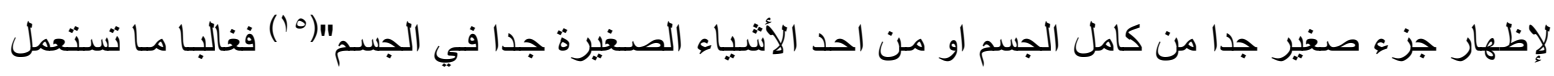
هذه اللقطات لتصوير العيون او الفم او الأذن او الأيدي او خانم او أي تفصيل للأشياء المحيطة بالثخصية، بسبب الحاجة الى حشد أجزاء دقيقة ومحددة من السرد الروائي للفيلم حيث من الممكن ان يكون لها أعظم اثر الثري

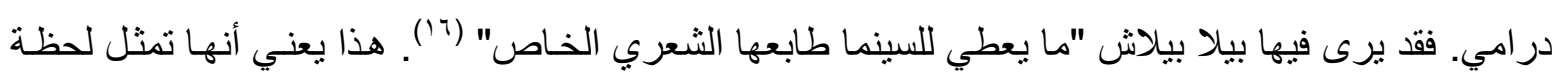
مهمة في الإطار الدرامي، فنجد استخدامها لدى اغلب المخرجين يؤجل الى اللحظـات ذات المعنى الدرامي

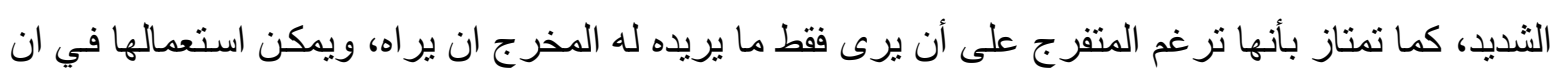
نبين ان الممثل لا يفعل شيء سوى ان يتكلم حوار مهم متصل في الخط الدرامي. يمكن للقطـة القريبـة أيضـا أذا ما أردنا ان نبين ردة فعل الثخصية، من خـلال البقاء على وجـه الممثل وصوت المئل المثنل المحاور من خـارج الكادر او الإيحاء بالقول من خلال لقطة قريبة لوجه الممثل. ان استخدام هذا الحجم في الفيلم يجعل المشـاهد

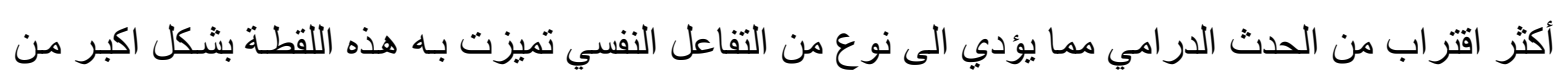
الحجوم الأخرى فنجد ان " اللقطة القريبة تحملنا الى علاقة أكثر جو هريـة وحميميـة مـع الموضوع عن الذي يدور

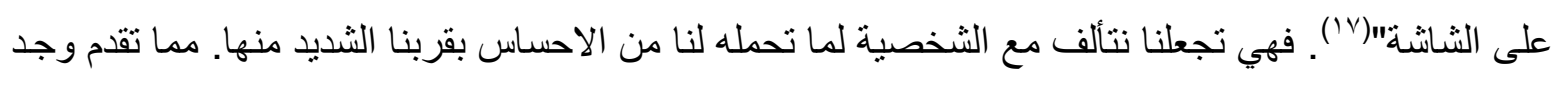
الباحث ان للقطة خاصية حمل أكثر من معنى، من خلال ربطها في السياق المشهد او السياق العـام للفيلم. كمـا

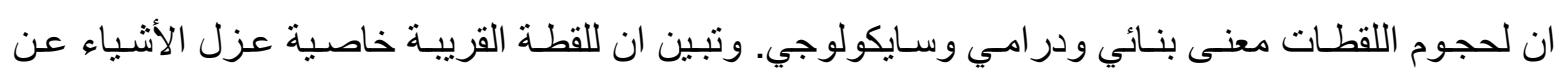

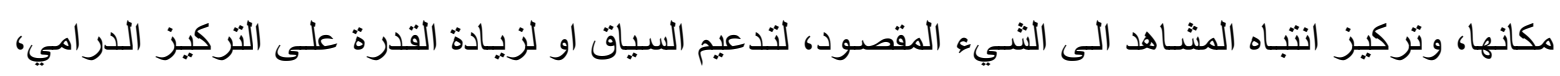
والاقتر اب اكثر من ذات الثخصية والإحساس بالنزعات الداخلية.

\section{المبمث الثاني: الرويا الفلسفية في أفلام برغمان:}

كثيراً مـا قر أنـا عن السينما كونها صناعة وفن، ويرى الباحث ان يضـاف إليها وفكر، ذللك لان

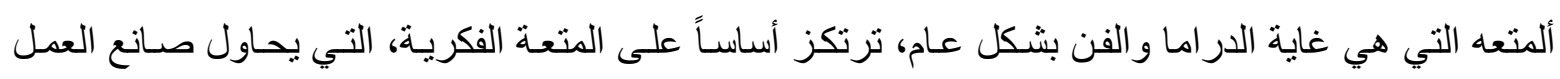
مخاطبة متلقيه من خلالها. ولو استقر انا حياة وسيرة الكثير من صناع الأفلام سنجد إن اغلبهم يكاد إن يُقر بـأن 
أعماله تستند إلى فكرٌ معين سو اء كان هذا الفكر ينتمي إلى أيديولوجية معينه او رؤية ذاتية إزاء الحياة. إضـافة إلى ذلك هناللك حقيقة أخرى، هي عدم خلوا أب فيلم من الأفلام من التجربة الحياتية لصانعه، و المعطى الفكري

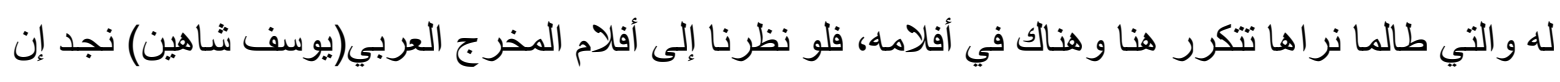

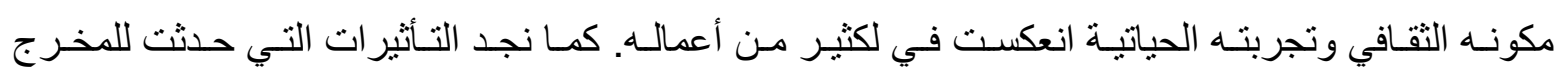
الانكليزي(الفريد هتشكوك) في طفولته وصباه من تربية صارمة ومخاوف الحياة بدت انعكاساتها واضحة في أفلامـه. ووجدنا انعكاسـات الحياة للمخرج الروسي(تاركو فسكي) بكل إبعادهـا، والتي بلورة شخصيته. و لا يخرج من هذا الإطار الذي تحدثنا أعلاه، موضوع البحث المخرج السويدي العالمي(انغمار برغمان) الذي قدم

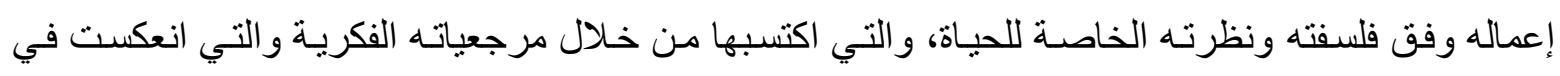

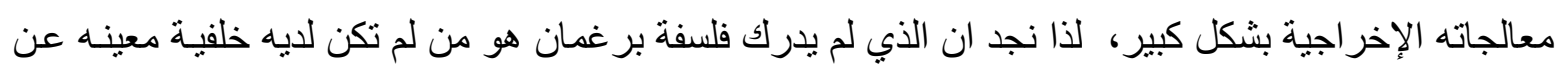

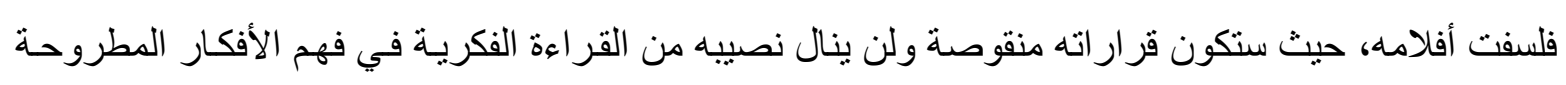

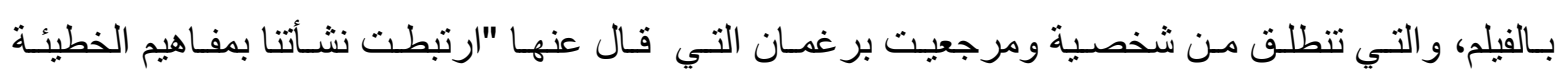

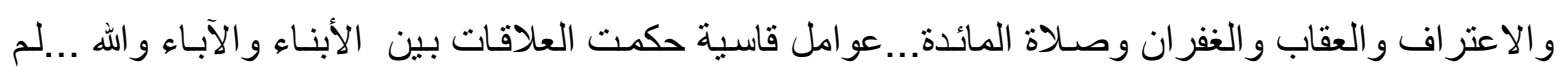

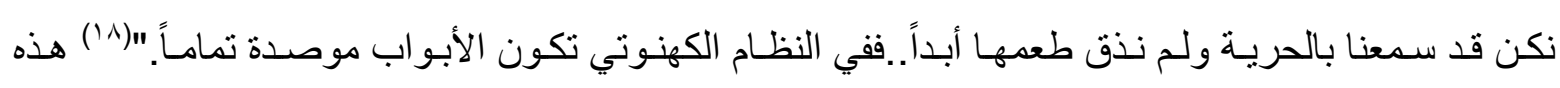

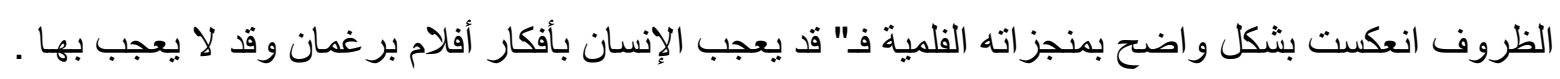
قد تثيره المشاكل التي يطرحها وقد لا تثيره ولكنه رغم ذلك سيستسلم لسحر فنه "(9"). لذا يأتي هذا المبحث ليحاول إعطاء الإيضاحات عن فلسفة برغمان ومصادر مكونه الثقافي وانعكاس و اقعه الاجتماعي على أعماله. يرى الباحث ان برغمان تعامل مع السينما ليس كمترف لمهنة الإخر اج السينمائي فحسب إنما،

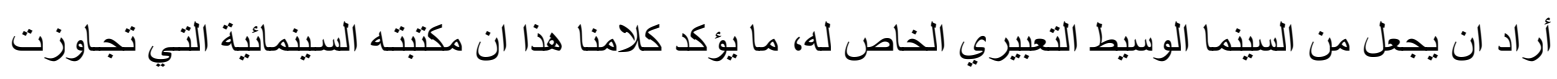
الخمسين فلمـا حملت كلهـا أفكاره الخاصـة "ولذلك فهو كاتب كل أفلامـه باستثناء خمسـة أفلام هـي (المينـاء) و(الظمأ) و(هذا ما لا يمكن ان يحدث هنا) و(فجر الحياه ) و(النبع)."(·) طالما حاولت السينما ومنذ بداياتها

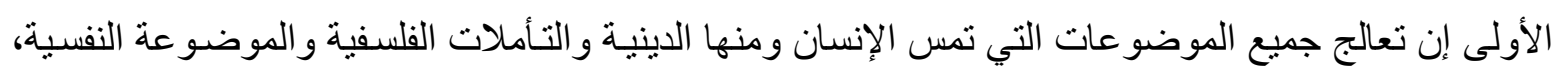
حتى "يمكننا ان نعود الى عـام 90 1 ، تحديداً إلى العام الذي ظهر فيه فيلم (الختم السـابع) للسويدي انغمـار

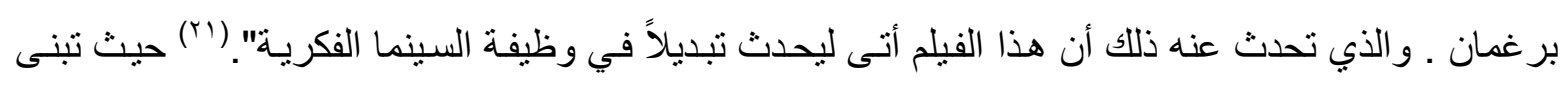

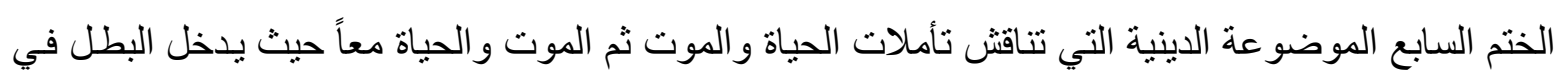
منافسة مـع الموت ليحاول التغلب عليه بمجموعة من الإحداث. وهو يخلق مقاربات بين الكوارث الصحية

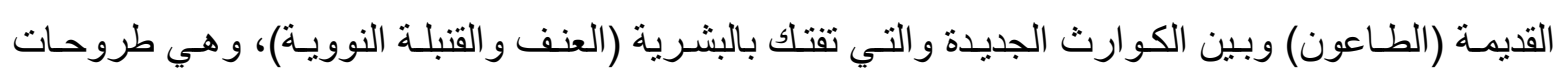

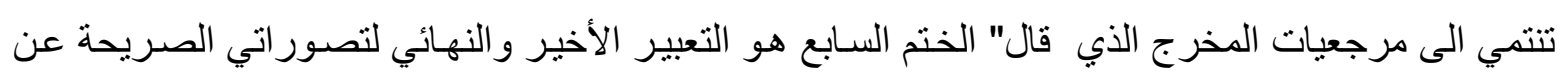

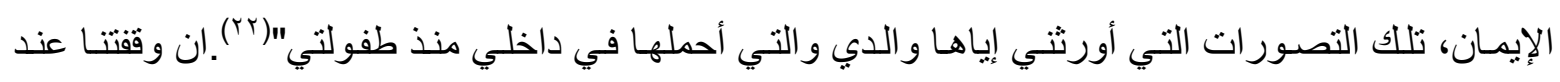
الختم السابع لم تكن لغرض إعطاء موقف نقدي بل لما أحدثه هذا الفيلم من إضافة في جعل السينما تتنهج نهجاً فكري جديد ف" من هنا صـار ثمة من يتحدث عن (السينما قبل الختم السـابع) و(السينما بعد الختم السـابع) كمـا

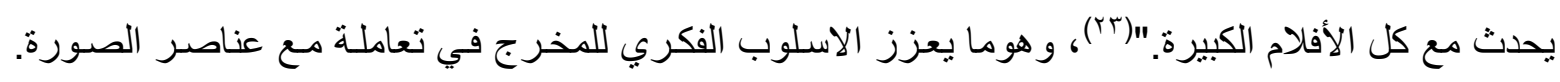

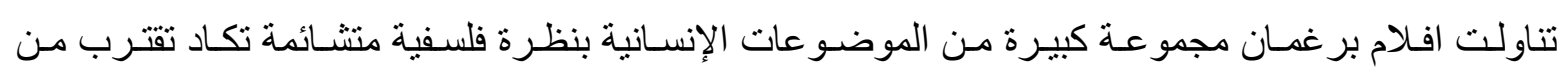


المأساة.مع التمبز في استخدام عناصر اللغة السينمائية وخصوصاً اللقطة القريبة موضو عة البحث، لمـا لها من قدرة على التعبير السايكلوجي ، انطلاقا من رأي بريغمان في "ان إمكانية الدنو من وجه بشري هي دون وفئ أدنى

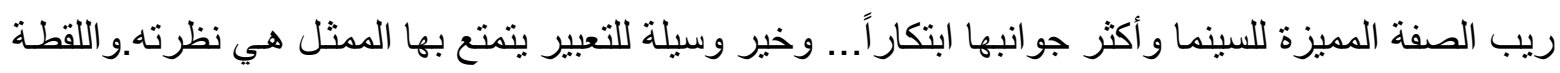

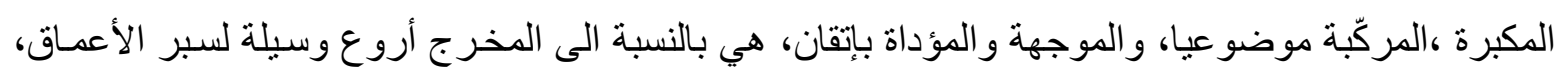
و أستطع دليل في الوقت نفسـه على جدارتـه أوعدم جدارتـه. ان وفرة اللقطات الكبيرة، أو بـالعكس غيابها،

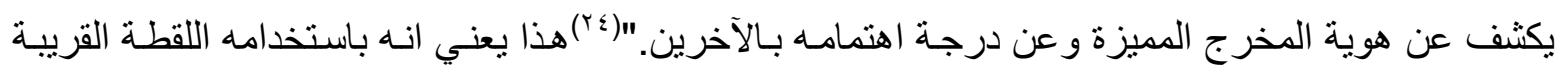

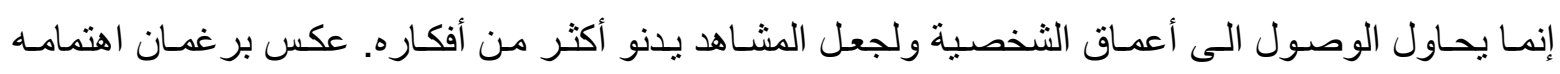
بتوظيف اللقطة القريية على الكادر الذي اعتاد العمل معهم من مدير تصوير وممثلين ليجعلهم يولوهـا اهتمـام خاص حيث كان لأبرز ممثلاته (ليف اولمان) وجهة نظر عن اللقطة القريبـة بقولها:" أحب اللقطات المكبرة

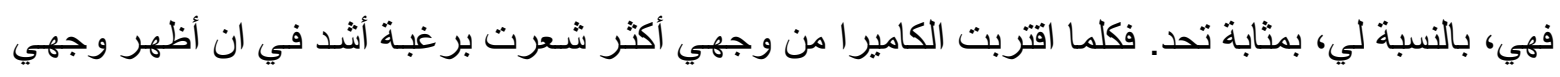
عارياً، في أن أكثف عما يختبئ خلف البشرة، خلف العينين، داخل الر أس...ان الكامير ا تلقاني مستباحة، حتى لتى أكثر من العشيق الذي يتخيل أنة قرأ أفكاري."(ro) من خلال ما قدم بريغمان في مكتبة السينمائية، نوظيف كثير

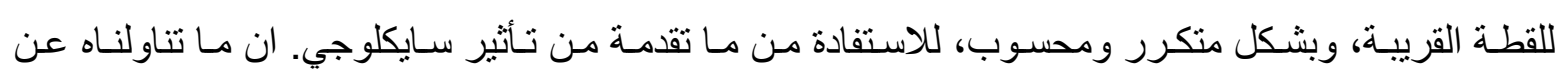
بر غمان و المؤثرات التي انعكست في عالمـة السينمائي وموضو عاته ونو احي الجمال ومحاو لاته الغور في

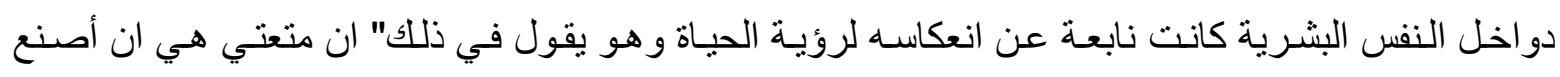

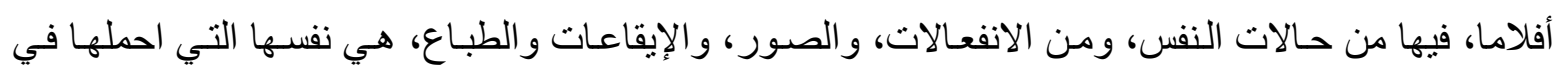
أعماقي"(Tr). فالذي يقر أه السيرة الذاتية لبر غمان يجد ان أفلامه قد عبرة عن جميع المو اقف الحياتية وتأملاته الإنه

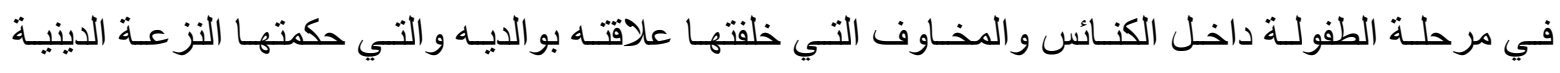
وقسوتهما، و علاقة المر أة بالرجل التي تأتت من علاقة أبوية وتخيلاته العاطفية. كل هذه الأمور أسهمت في ان

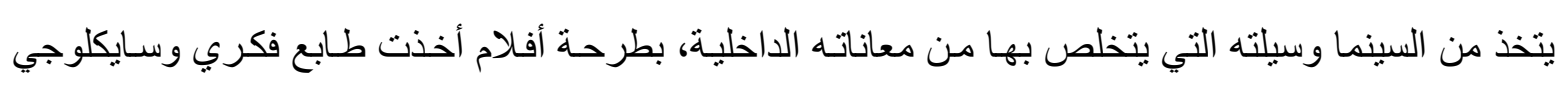
تركت بصمة مميزة في تاريخ السينما.

\section{هوثرات الاطار النظري:}

اـ تمثل اللقطة القريبة غوص في أعماق الثخصية وكثف عن دواخل النفس البشرية. r- تعمل اللقطة القريبة على جذب انتباه المشـاهد للتركيز او للتاكيد على شيء يرتبط بعلاقة سياقية، تعزز التأثير السايكلوجي للشخصيات، داخل بنية الفيلم. r- يمكن للقطة القريبة أن تمثل ردة فعل أو استجابة نفسية للشخصية داخل بنية المشهد.

الفصل الثالث:( إجراءات البمث)

أولا: هنهج البمث:

اعتمد الباحث في انجاز هذا البحث على المنهج الوصفي التحليلي والذي يعرف بأنه "أسلوب في

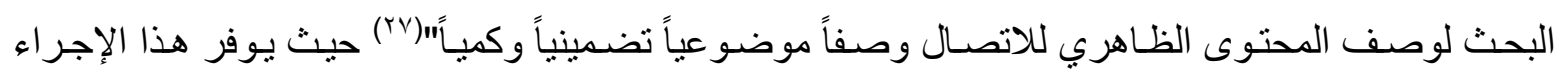


إمكانيـة الكثـف عـن التوظيف السـايكلوجي للقطـة القريبـة في أفـلام بر غهــان،عبر تحليـل العينـات المختـارة للوصول الى أهداف البحث .

\section{ثانيا: هجتمع البمث: أفلام المخرج العالمي (انغمار برغمان).}

ثالثا: مينة البمث:

تم اختيار عينة البحث، وهي فلمين للمخرج انغمـار برغمـان والتي تم خلالها توظيف اللقطـة القريبـة سايكلوجياً، وعينة البحث جاءت على النحو الاتي: فيلم:(القناع) فيلم:(التوت البري).

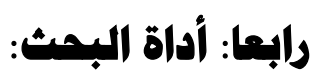

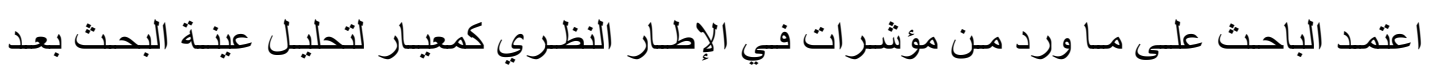

استحصال موافقة لجنة الخبر اء و المحكمين عليها.

خامسا: وصدة التمليل:

اعتمد الباحث على اللقطات القريبة ذات التوظيف المميز وكذلك بعض المشـاهد المتضمنة لعدد من اللقطات القريية ضمن إطار بناء المشهد.

\section{الفمل الرابع: (تمليل العينات المثتارة)}

(PERSONA،1966): فيلم القتاع

تمثيل: (بيبي أندرسون BIBI ANDERSSON)،ليف أولمان(LIV ULLMANN) تصوير : سيفين نكفست (SEFEEN NKFES) سيناريو واخر اج: انغمار بر غمان (INGMAR BERGMAN)

تدور قصة أو قضية القناع حول ممثلة مشهورة تدعى" اليز ابيث فو غلر" (ليف اولمـان) نجدها فجأة و هي تتخلى عن كل أدوارها في المجتمع وأصبحت غير عازمة على الحركة تماما بتخاذها الصمت التام إزاء الحياة. حيث يوضتح لنـا الفيلم الدو افع التي قادتها الى الصمت الذي اختارتـه "اليزابيث" من خـلال مشـهدين الأول نرى فيه راهبا بوذيا يحرق نفسه في التلفزيون و الثاني تتأمل فيه صورة ثابتة من صور الحرب العالمية

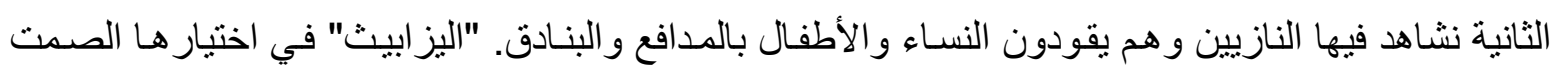

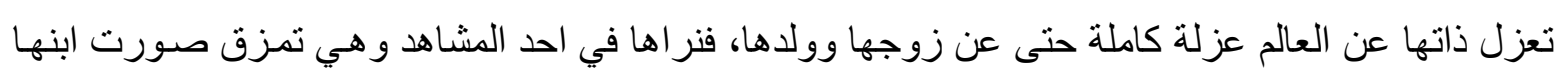

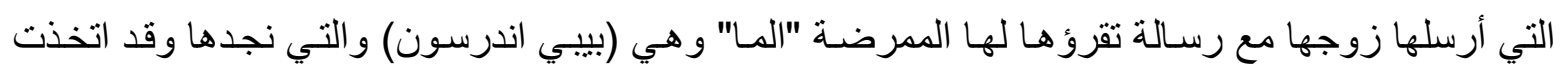
الموقف المناقض لموقف "اليزابيث"، حيث نراها تثرثر طو ال الفيلم عن إحزانها العاطفية وتتطلق دون رابط تعبر عن نفسها لمريضها وتفتح له قلبها. ثم نجد "اليزابيث" تصطحب " ألما" معها الى دار هـا الصيفية الكائنة في جزيرة معزولة بعد ان تتصحها الطبيبة النفسية بذلك.

في البدايـة تعجب "ألمـا" بأليزابيث" وتشـعر اتجاهها بـالعطف وتدور بينهم إحداث توضـح مدى

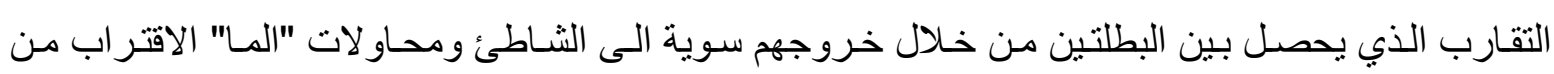


"اليزابيث"، لكن "الما" تفاجأ ذات يوم وهي تطـالع رسـالة وجهتها "اليزابيث" الى طبيبتها وهي تخبر هـا عن

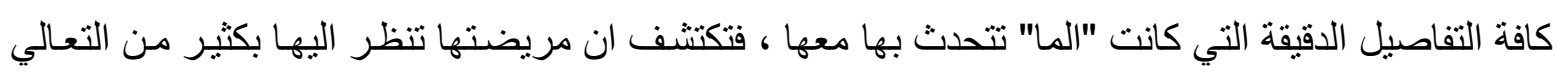

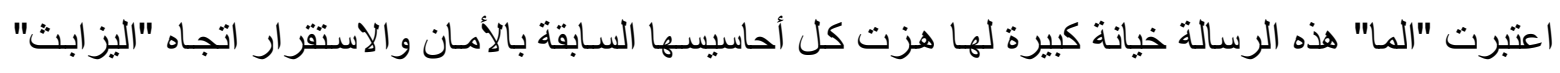

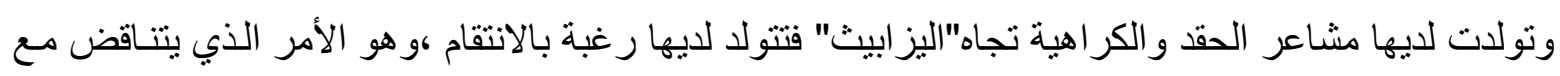

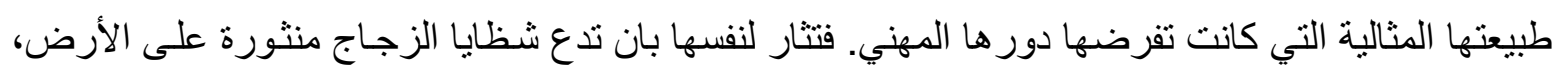

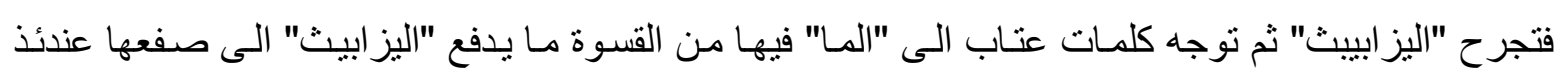
تمسك "المـا" بطشت من المـاء المغلي وتهدد بـان تسفحه على "اليزابيث" وهذه المو اجهه بين الاثنين تمكن "الما" من كسر طوق الصمت لدى "اليز ابيث". بعدها تسيطر على الثاثنة أجواء حميميه، وتتطور العلاقة بين بين

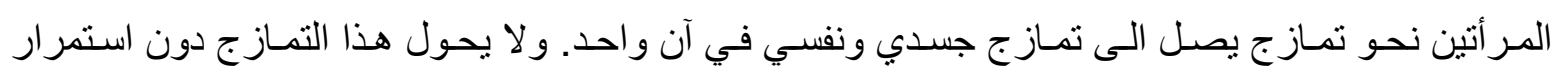

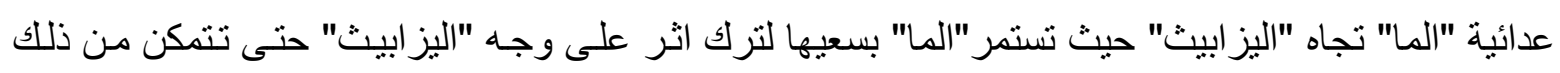

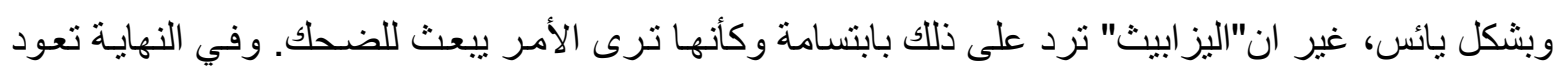

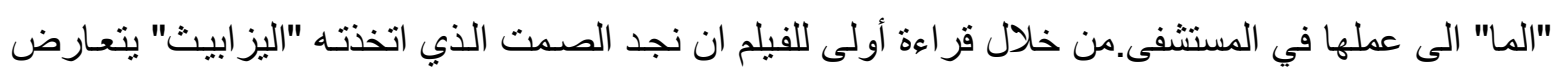

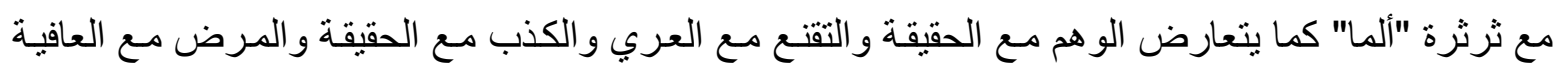
و الدمار مع الخلق و الموت مع الحياة.

\section{اولا: تمثل اللقطة القريبة غوص في أعماق الشفصية وكثف عن دواخل النفس البشرية.}

يمكن ان تكـون اللقطـة القريبـة واحده مـن أفضـل العناصـر التتي يستغلها صـانع العمل لخلق التأثير السـايكلوجي على المتلقي حيث يحساول من خلالها استبطان دواخل النفس البشرية فهي تجعلنـا الأقرب لكل الأشياء. في فيلم برسونا وفي المشهد الذي يدور في المستشفى حيث تدخل الممرضـة "المـا" الى غرفـة الممثلة المريضة "اليزابث" وتتحدث "الما" مع "اليز ابث" التي تتخذ موقف الصمت التام مع كل من حولها ...ثم تخرج "الما"..."اليز ابيث" نائمة وبلقطة قريبة، وهي تنظر طويلا دون ان يطرق لها جفن، وتبدأ الإضـاءة الامامية للثخصية بالتظائل التدريجيا، ليصبح وجهها الممثلة (سلويد) ثم تدير وجهها حتى يصبح بوضع (بروفيل)

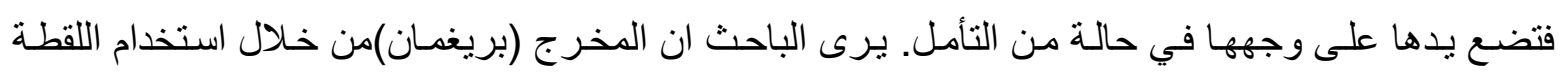
القريبة وتوظيف المتغير الضوئي بين النظرة السوداوية في داخل "اليزابيث" التي تبدو وكأن الحياة تظلم إمـام أعينها، و هي حالة شعورية ترتبط بالوضع السايكلوجي للشخصية .

في المشهـد الذي نرى "اليزابيث" في حجرثها الخالية تمامـا من الأثاث حيث الجدران البيضـاء وسرير نوم وجهاز التلفاز فقط ... صوت مظاهرات يصدر من خلال التلفاز، "اليزابيث" وهي بملابس النوم

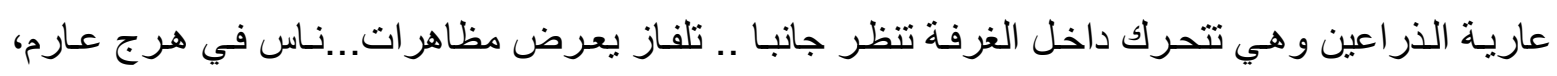
بوذي يحرق نفسـه وهو جـالس على الأرض منتصب يقاوم ألم النبران المرتفع لهيبها مسن ملابسـه وجسـده

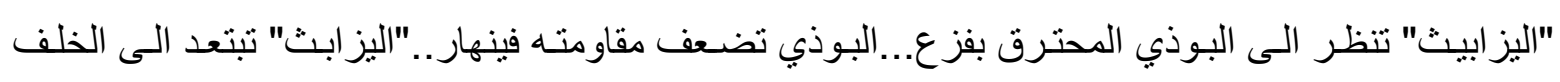

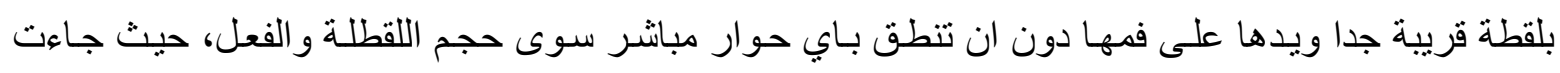

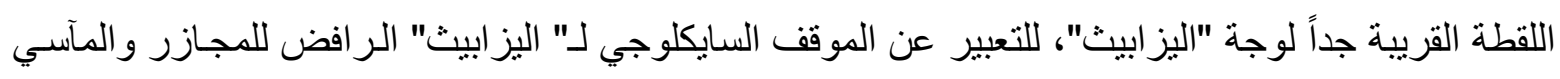


التي تحصل في فيتتام من قبل القوات الأمريكية وان كل مـا شـاهدته ممـا يدور في الواقع إثارة لديها نزعة داخلية عبرة عن رفضها المطلق للقسوة التي يتعرض لها بنو البشر على يدي أبناء جنسه.

كمـا وفي المشـهد الذي نشـاهد "اليزابيث"و"المـا" في غرفـة النوم حيث تكـون "اليز ابيـث" في بقعـة الإضـاءة المركزة تجلس على السرير و"المـا" تتحدث في الجزء المظلم على الكرسي المقابل للسرير، وهي بلقطة قريبة تتحدث "الما" لتلقي جميع همومها الداخلية وهي تتألم، ومعـه استمرار حديث "المـا" عن حياتها الخاصة نشاهد وجه " اليزابيث " بلقطة قريبة، وهي تمسك بيدها اليمنى سيكار ، ويمتد زمن اللقطة لمدة طويلة

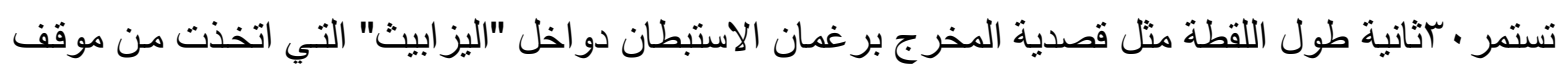
الصمت وسيلة لتعزل نفسها عن الآخرين.

في المشهد التالي تظهر لنا "الما"و اليزابيث"وهما ينامـان على سرير واحد وبلقطة دتبلز حيث يكون

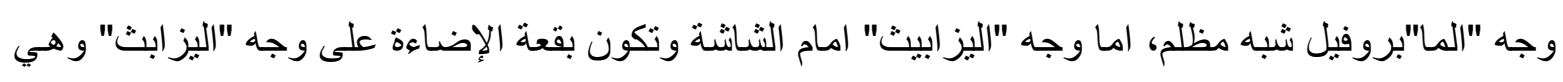

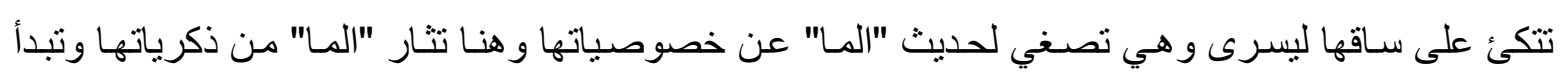
بالبكاء وتدير وجهها باتجاه العدسة ليكون وجهها الوحيد في الثانــة بلقطة قريبـة جدا و الإضـاءة سلويد) فقد استخدمت هذه اللقطة القريبة لمحاولة للتأكيد السايكلوجي، على مدى الظلمة التي في داخل "الما". عندما ذهبت "الما" الإرسال البريد الذي بعثته "اليزابث" الى الطبيبة وهي تقود السيارة ثم تنظر الى

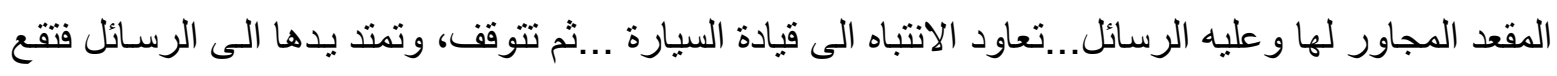

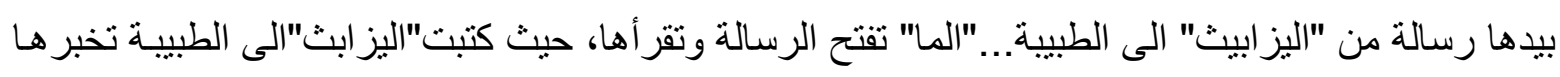
عن أدق التفاصيل التي كانت "الما" تتحدث بها معها، وتصف نفسها بأنها مر اقب هـادئ ونزيه وتتسلى بذلكانك الحديث. اعتبرت "الما" الرسالة خيانـة قاسية هزت كل أحاسيسها بالأمسان والاستقرار وتولدت مشـاعر الحقد و الألم الثديد بسبب ما حدث. و انتابتها " الما" الرغبة بالانتقام، وهي مشاعر تتعارض مع ما كانت نابعة منها، وتتناغم وطبيعة واقعها المهني. استخدم المخرج لقطة قريبة لوجه "المـا" اعلنت للمشـاهد بعداً سـايكلوجين مهم أبرز و هو لحظة التحول في داخل نفس "الما". في المشهح الذي نرى "الما" بعد ان تنتر قطع من الزجاج على الارض لتنتقم من "اليزابث" بسبب

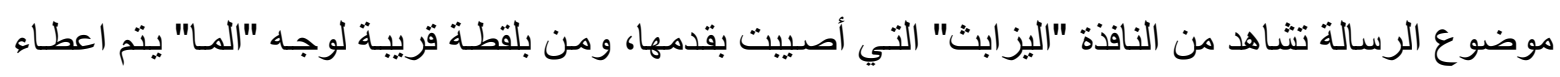

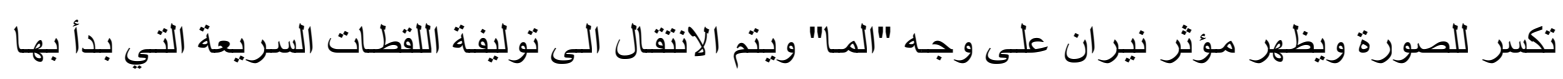
الفيلم، عبرة عن عبث الموقف الداخلي لنفسية "الما".

هنالك مجموعة اخرى من اللقطات شتغلت ضمن اطسار هذه المؤشر غير ان المقام لايتسع لذكر ها بسبب محددات البحث. 


\section{ثانيك: تعمل اللقطة القريبة على جذب انتباه المشاهد التركيسز او للتأكيس على شيسي يسرتبط

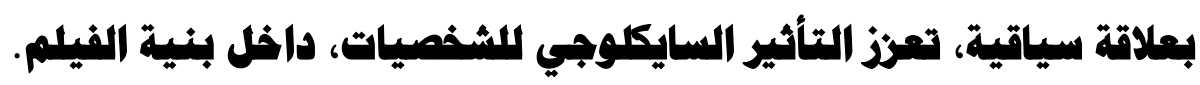

ان للقطـة القريبـة خاصـية عزل الأشـياء عن محيطهـا المكاني، وتركيز انتبـاه المشـاهد السى الثـيء المقصود، الذي يرتبط ببمنـة المشهـه بشكل خاص او الفيلم بشكل عـام، والذي غالبـا مـا يحقق اثر سـايكلوجي ونري يحكم سلوك الثخصيات.

في المشهر الذي تظهر لنا "الما"في غرفة "اليزابث" داخل المستشفى، وهي تقرءا لها رسالة بعث بها

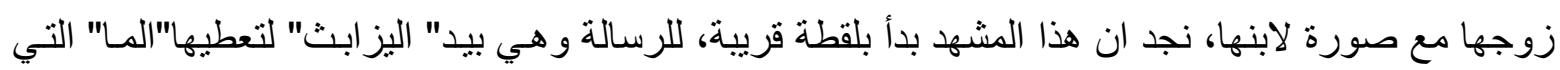
تقوم بـدور ها بقر اعة الرسـالة الى "اليز ابيثث" فهنـا نجد اللقطـة القريبـة وظفت لتركيز الانتبـاه على الرسـالة

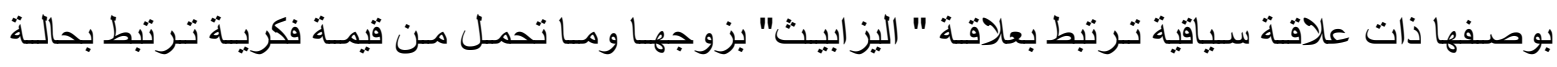
سايكلوجية قابعة في نفس " اليز ابيت" والتي تبلورت من خلال ردة فعل "اليزابث" اتجاه الرسالة.

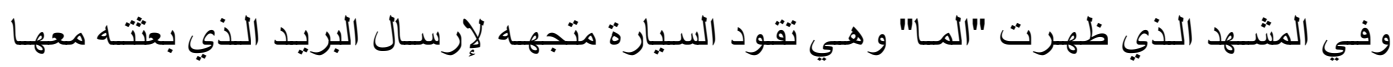

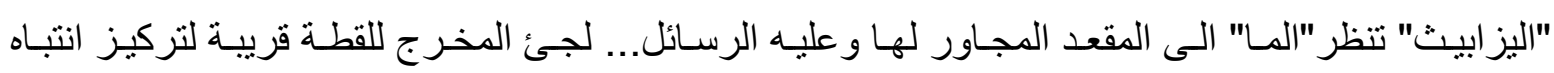
المشـاهد للرسـالة لمـا حملت علاقة سياقية ترتبط مضهون تم الكثف عنسه فيمـا بعد والذي اثر على التحول السايكلوجي للثخصية، احدث نقطة تحول لدى البطلة فيما بعد، وتم عرض محتوى الرسـالة والتركيز علية و هو يملا الثاثة لغرض إدر اكه من قبل المتلقي و التأكيد على اهمية اللقطة القريبة التي سبقتها. في المشهر الذي تدور فيه مواجهه بين البطلتين، حيث تضرب "اليزابث" بقسوة "المـا" يتم القطع الى لقطة قريبة الى إنـاء فيهه مـاء مغلي، تهرع "المـا" الى اخذ المـاء المغلي الذي شـاهدناه في اللقطـة القريبـة

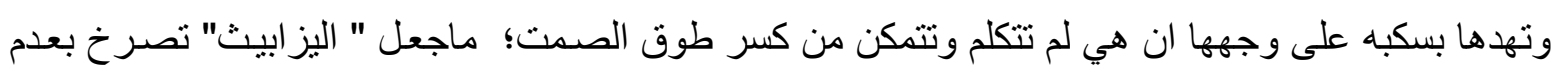

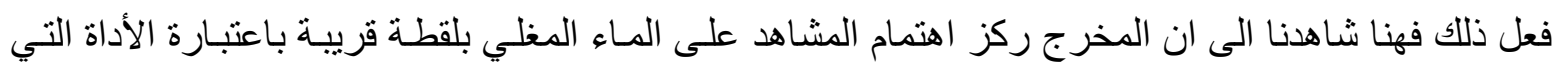

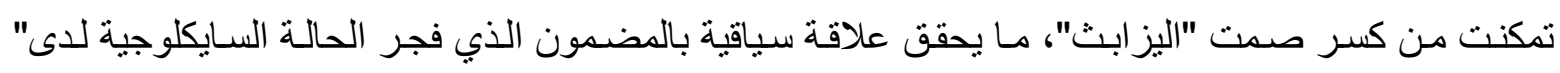
اليز ابيث".

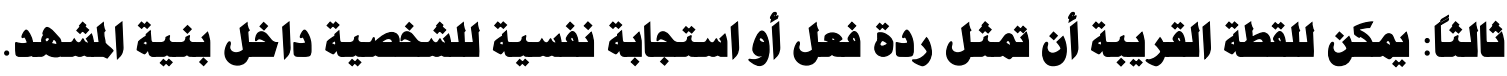

في المشهد الذي تدخل "المـا" على الطبيبة النفسية حيث تبدأ الطبيبة بالحديث الطويل عن حالـة "اليز ابث" ووصفتها بأنها نرغب في طرد كافة المواقف والأدوار المزيفة والكاذبة من حياتها.تأتي هنا لقطات

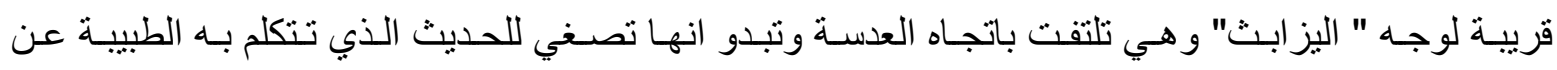
حالتها.حيث مثلت القطـة القريبـة هنـا ردة فعل تنظمن استجابة،"اليز ابث" إز اء مـا تسـع عن حالتهـا بحديث الطبيبة ـ ثم تأتي لقطات قريبة لوجـه "المـا" ومن زاويتين مختلفتين وهي تستمع للطبييـة التي تستمر بحديثها الطويل عن "اليز ابث" هذه اللقطات تبين ردة فعل "الما"|تجاه حالت "اليزابث" حيث بدأت تثـعر بنوع من

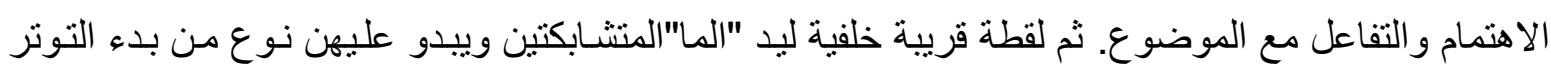


حيث يعطي هذا التوتر الذي برز من خلال لقطة قريبة ليديها المتشـابكتين خلف ظهر هـا، ردة فعل أولية اتجـاه ما تسمعه من قبل الطبيبة.

وفي المشهد الذي نجد "الما" تقر أ على "اليز ابث" الرسالة التي بعثها زوجها لها، تأتي لقطة قريبـة "اليز ابث" للتعبير عن ردة الفعل القوية لها وكأنها فزعة من ما سمعت، وكأن الرسـالة ثورت بركان في داخل "اليزابيث". كما ان المشهد الذي تظهر به "اليزابث" تقشر تفاحة وتكون الطبيبة خلفها وتتحدث لها طالبة منها ان تقضي فترة في بيتها الريفي خارج المستشفى، تأتي لقطة قريبـة "ليز ابث" وهي تستمع لحديث الطبيبـة ثم تتحرك الكاميرا (tell Dion) على يدها بلقطة قريبة وهي تقتـر التفاحة بتوتر، حيث مثلت هذه القطـات القريبة ردة فعل نقسي، لم يتم الاعلان عنها بشكل مباشر لكن جائت بشكل واضحة "ليزابث" الر افظة لمقترح

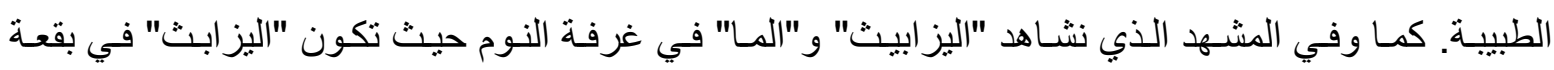
الإضـاءة المركزة تجلس على السرير و"المـا" تتحدث في الجزء المظلم على الكرسـي المقابـل للسرير ثم تتحرك لتجلس على مسطبة في أخر الغرفة، ومعه استمر ار حديث "المـا" عن حياتها الخاصـة نشـاهد وجـه " اليز ابيث " بلقطة قريبة وبصمتها المعتاد حيث مثلت القطة ردة فعل صسامته كصمت"اليز ابيث" التي اتخذت من الصمت وسيلة لتعزل نفسها عن الآخرين. بعد ان حصل التداخل بين "الما"و"اليزابث" وارتدت "الما" قناع "اليزابث" في تعاملها مـع الزوج

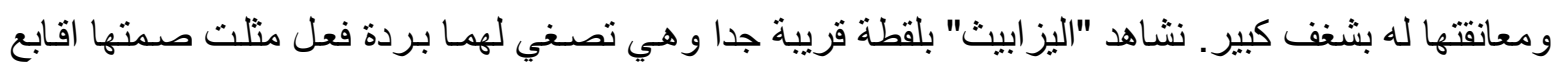
في ذاتها والذي بقي مستمر اتجاه كل من حولها.

الفيلم: التوت البري) "WILD STRA WBERRIES "1957) تمثيل:فيكتور شوستروم (Victor sjostrom) انجريد لوتش (Ingrid thulin) سيناريو وإخراج: انغمار برغمان (Ingmar Bergman) ان فيلم التوت البري من الأفلام التي اهتم بها بر غمان بما يعانيه الإنسـان المعاصر بشكل خـاص فهو

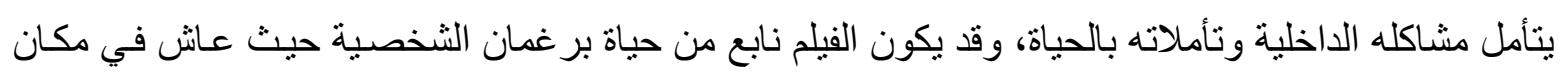
ينمو فيه التوت البري وهي نفس الذكريات التي يعود بها بطل فيلمه حيث تمر عليه ذكريات المكان الذي ينمو به التوت البري، ويمكن اعتبار هذا الفيلم من الافلام التي لا تميل الى التشاؤم.

تدور أحداث الفيلم حول قصـة الدكتور (إيزيك بورغ) البالغ من العمر V7 سنة والذي يعيش مـع ذكرياته لزوجته (كارين) التي ماتت منذ زمن طويل وتركته يعيش لوحده مع مديرة منزله (اكادا) ولديه ابنته

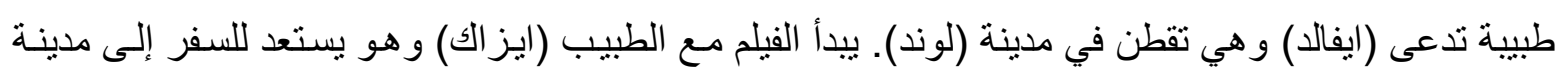

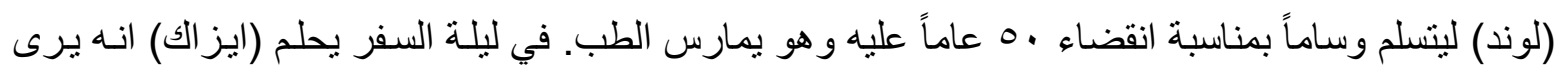

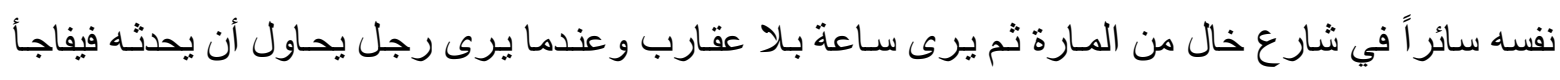

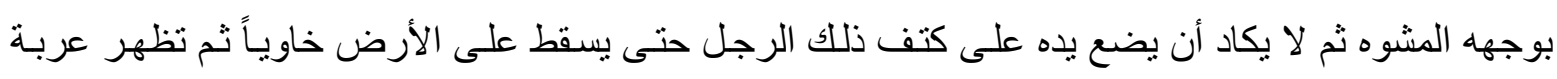
تكاد تصطدم به ويسقط منها تابوت تخرج منه جثة هي جثته تمد يدها لسحبه معها فحينها يستي قظ الدكتور 
(ايز اك) من كابوسـه مستغربا ليبلغ مديرة المنزل انه سيرحل على الفور إلى (لوند) فتطلب منـه (ماريـان) زوجة ابنه ان تسافر معه لتعود لزوجها.

في الطريق يدور حديث بين (ايزيك) و(ماريان) عن مبلغ من المال استعاره زوجها من (ايزيك) الذي

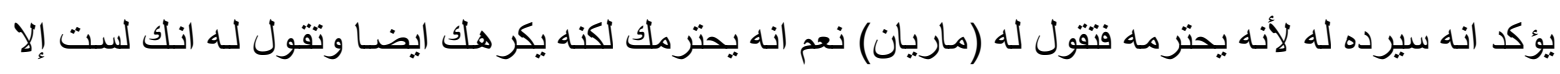

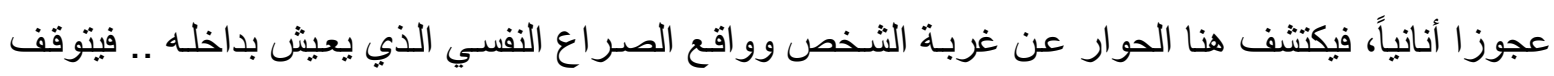
عند منزل قديم ومهجور كان (إيزيك) قد قضى شبابه أو طفولته هنالك أو فيه، فيستغرق في ذكرياته لنرى فئ فئه (سيجفريد) يغازل (سار ا) حبيبة (ايزيك) التي كانت تقطف بعض التون ائوت البري.

ثم نرى العائلة كلها مجتمعة على مائدة الطعام التي يقدمون فيها توت بري للعم العجوز ثم نرى

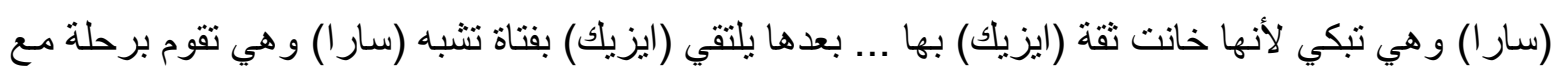

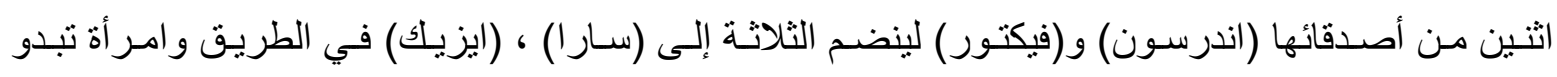

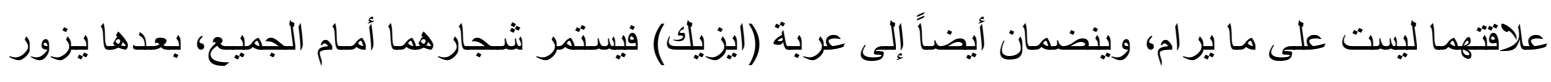

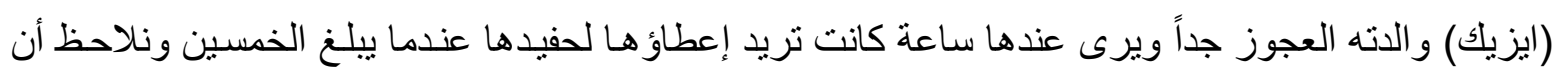
الساعة بلا عقارب وخلال الطريق تدور نقانشات حادة بين (أندروس) اللذان يريدان أن يصبح قساً و(فيكتور )

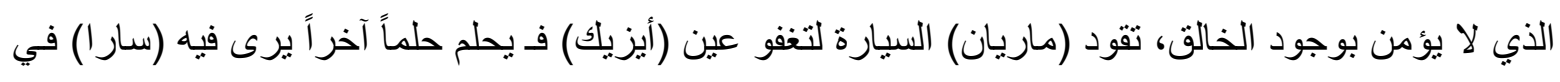

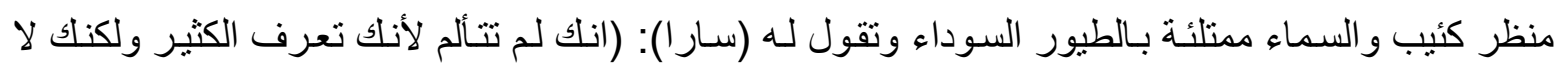
تعرف شيئًا) فتنصـرف (سـار ا) ويتبعها (ايزيك) إلى المنزل الذي رآهـا فيه مع زوجها، يدق البـاب فيخرج الرجل الذي رأيناه من قبل تشاجر مع زوجته في السيارة. فيأخذه إلى مدرج يجلس فيه كل ر اكبي السيارة و هناك يحدث استجو اباًاًلايزيك) وكأنه في امتحان في

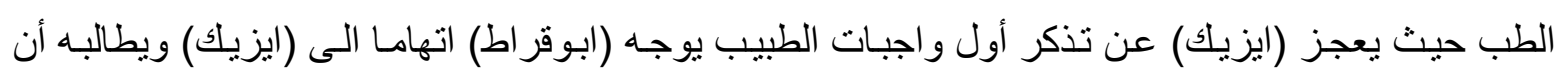

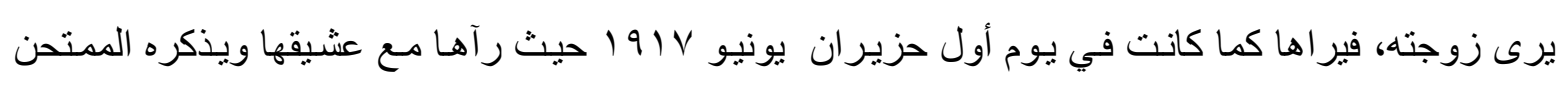
كيفية انتقامه منه ويحكم عليه بالوحدة ليستيقظ ويقول: (ماريا أنه من الممكن أن يكون الثخص ميت ريت رغم رغم أنه حي فتقول له (ماريا): (أن ايفان يشبهه لتروي لله قصة خلافهما حول الطفل الذي ننتظره و لا يريده هو)، ثم

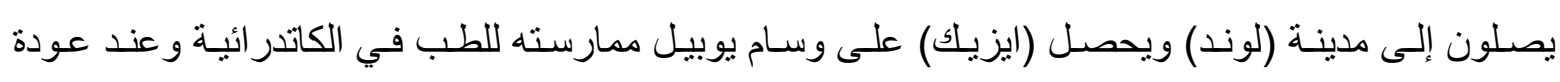
(ايزيك) الى المنزل يحاول الاقتر اب من الآخرين ومنهم (آكادا) مديرة المنزل، لكنها تصده. ثم يستدعي ابنه (ايفـان) ليحادثه بثـأن زوجته ليجعلهما يتفقان حول طفلهمـا القادم، وقبل أن ينام

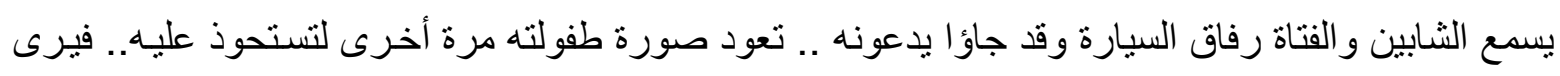

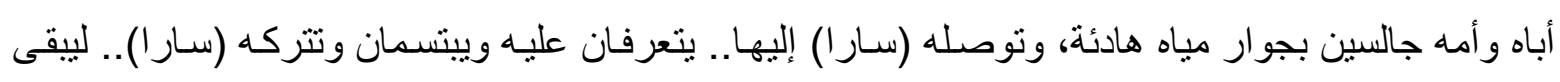
مهزوزاً و على وشك البكاء.. ليعقد صمتاً مع الحياة. هذه قصة الفيلم. 


\section{اولا: تمثل الاقطة القريبة غوص في أعماق الشفصية وكشف ها بدواظل النفس البشرية:}

المشهد الأول الذي نجد فيه (إيز الك) يجلس في مكتبه داخل منزله وهو يتحدث بحوار عن علاقته مـع

الآخرين حيث يقول: لقد قررت أن لا أرى من يعيشون من حولي .. لكي أبقى في وحدة كاملة، نرى هنـا

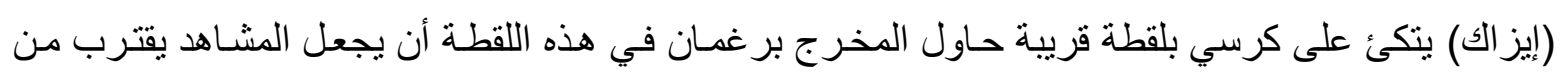

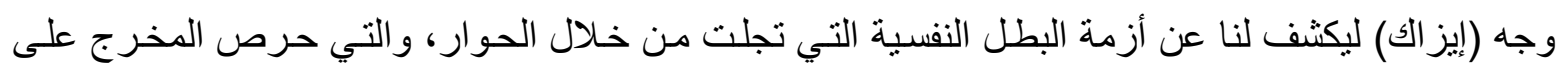
تأكيدها من خلال اللقطة القريبة.

في المشـهـ الذي رأينـا فيه (إيز اك) ينـام استعدادً للسفر في الصباح التـالي ليحلم: بلقطة قريبـة لدى تجو الة وحيداً في الثـارع عبرت عن غربته عن كل مـا يحيط بـه، بنفس مشهـد الحلم بعد أن رأى (إيز الك) الرجل القبيح الذي أنهار أمامه، توجه باحثاً في الثار ع الخالي، تأتي هنا لقطة قريبة لوجه (إيز الك) عبرت عن عن

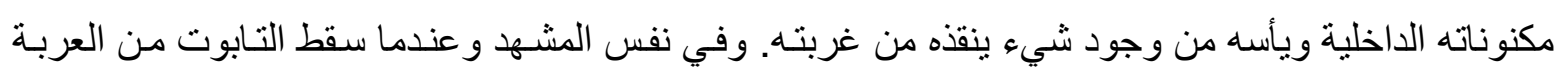
ونظر (إيز اك) إلى يد تخرج من التابوت تظهر لقطة قريبة لوجه (إيز اك) عبرت عن عمد ون مخاوفه لرؤيته يد

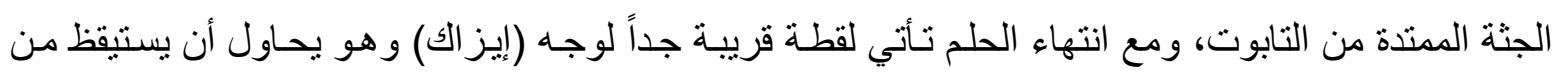
الكابوس ليفتح عيناه وينظر باتجاه الكاميرا للتعبير عن مخاوفه الداخلية وفزعه من هول مار رآه في الحلم. عندما ينزل (إيز اك) و(ماريان) عند منزل قديم ومهجور كان (إيز اك) قد قضى طفولته وشبابه فيه

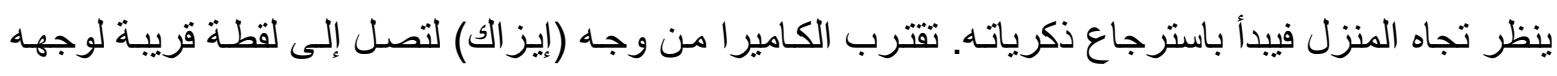

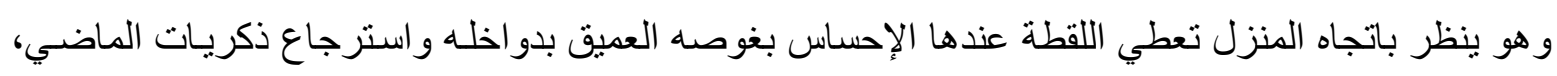

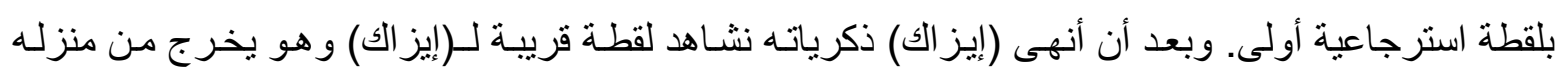
ويبدأ استرجاع ذكرياته بالذوبان بلقطة استرجاعية قريبة ثانية.

في المشهد الذي يزور فيه (إيز اك) و الدته و عندما كانت تريه ساعة كانت قد ادخرتها لحفيدتها و عندما

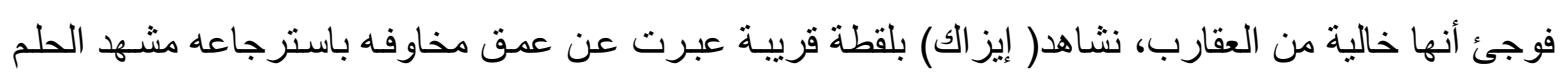

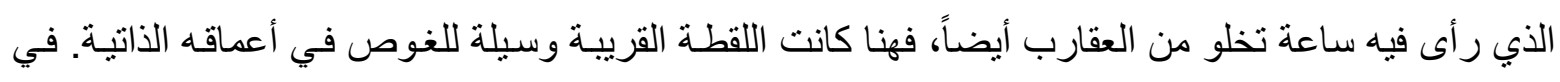

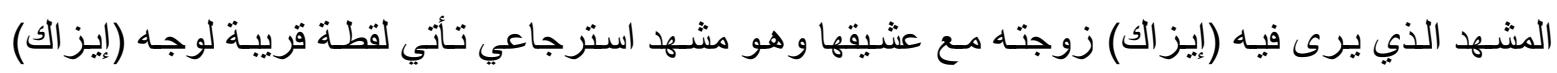

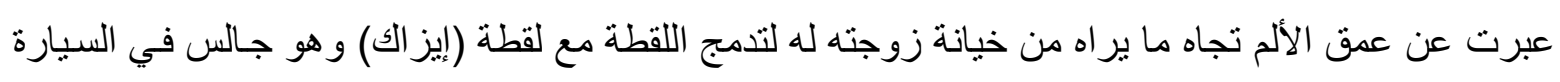
يستيقظ من هذا الكابوس.

\section{ثانيك: تعمل اللقطة القريبة على جذب انتباه المشاهد للتركيسز او التأكيس على ثـيـي يـرتبط

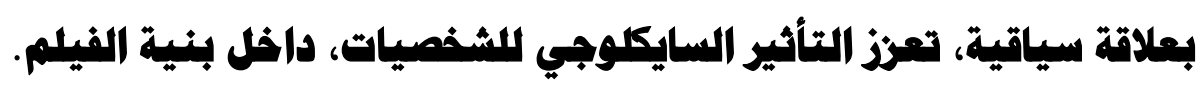

في المشهد الذي رأينا فيه (إيز اك) يجلس في مكتبه المنزلي متأملاً عدداً من الصور بلقطة قريب، محاولة للتأكيد على مجموعة من الصور التي تحيط به وهي صورة (ايفالد) ابنته، وتدور الكاميرا بنفس حجم اللقطة، صوت (إيز الك) مع زوجته (كارين)، و هنا ترتبط اللقطة القريبة سياقيا بفهم الحالة النفسية التي يعيشها( ايزيك) و اغتر ابة من هذا الكون. 
في مشـهد الحلم الذي كان (إيزاك) يسير فيسه وحيداً في الثـار ع نظر إلى سـاعة في الطريـق بـلا

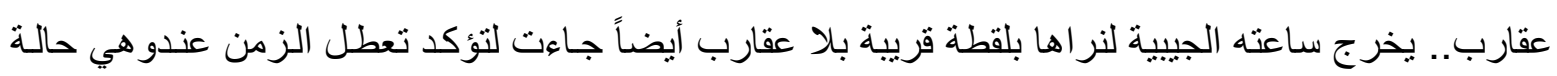

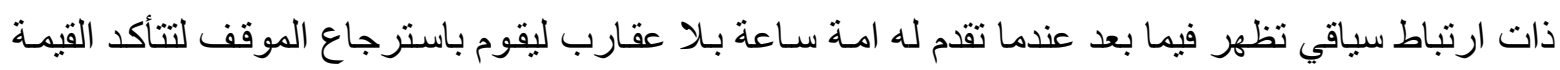

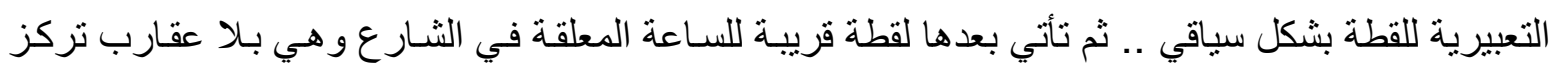
انتباه المشاهد وتؤكد لنا على تعطل الزمن بالحياة التي تحيط به؛ بعد ذلك وحينمـا سقط التابوت العربـة وشـاهد

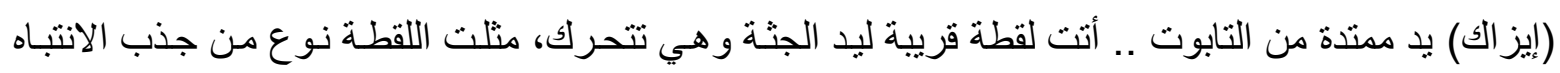

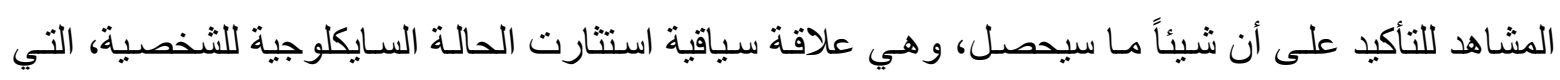
ادركت بعد ذلك الثبه بين الجثة في التابوت و(إيزيك). توالت لقطات التأكيد على وجهـ الجثة بحجمها القريب و القريب جداً بتقطيع سريع بين وجه الجثة ووجه (إيز الك).

في المشهد الذي نرى فيه (إيز الك) يجلس إلى جوار (ماريان) حيث يغلب عليه النوم فيشـاهد حلم فيها

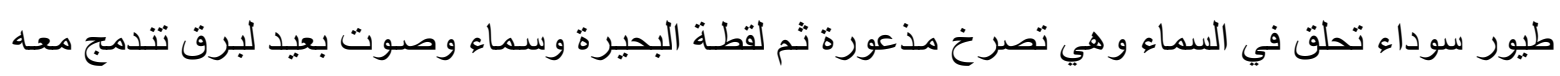

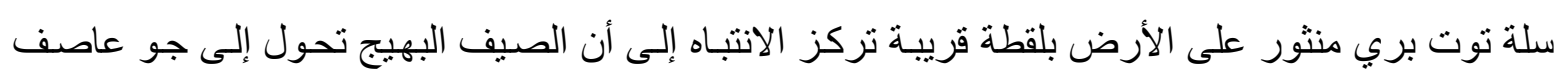

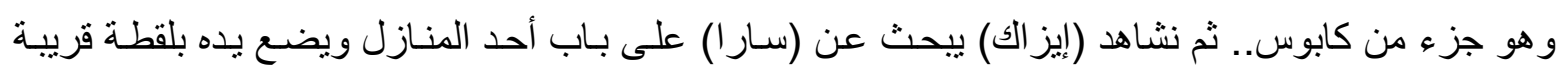
على مسمار من دون أن يشعر بجرح يده بالمسمار المعلق على الجدار، أتت لقطة هنا تحاول تركيز انتباه على لى إنى عدم و عي (إيز اك) لما حوله، كأنه من الاحياء الميتين الذي تحدث بلثن عنهم (ايزيك) في نهاية الفيلم.

\section{ثالثثا: يمكث للقطة القربية أن تمثل ردة فمل أو استبابة نفسية لافهمية داخل بنية المشهد.}

في مشهد الحلم الذي كان فيه (إيزاك) يسير وحيداً في الثار ع وعندما نظر إلى السـاعة المعلقة بـلا

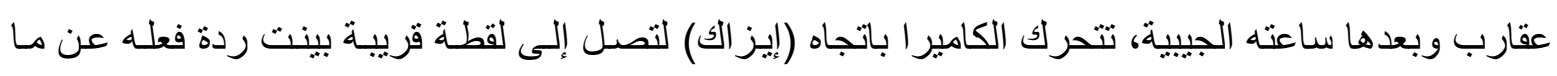
يرى حوله .. ثم يتنقل في الثار ع محاو لاً البحث عن شيء ما يدل على الحياة في المكان الذي يقف فيه فينظر

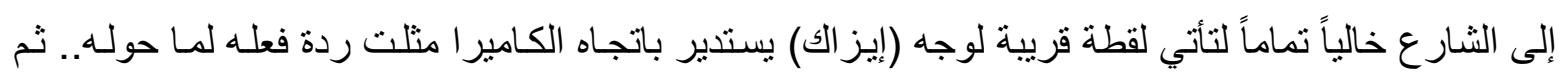
بعدها يشاهد (إيز اك) رجل يقف في الثارع .. هنا تأتي لقطة قريبة لوجه (إيزاك) (بروفيل) كردة فعل لرؤيته الرجل، يغادر بعدها الكادر متجهاً نحو الرجل الواقف. عندما توجه (إيزالك) نحو الرجل مدسكاً بكتفه محساو لاً

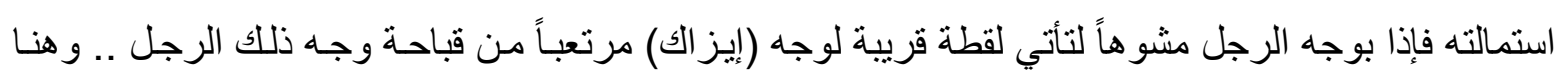

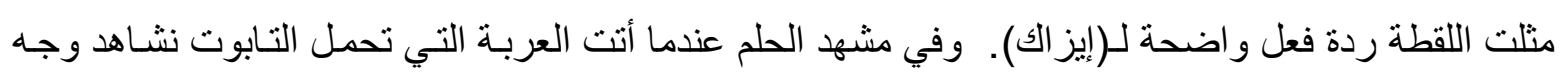
(إيز اك) بلقطة قريبة وهو ينظر إلى العربـة مستغرباً لوجودهـا تسير بـلا قائد وبعد أن تصطدم بأحد الأعمدة

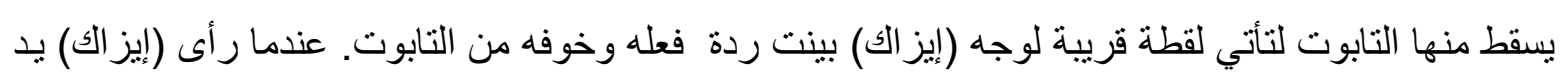
الجثة تتحرك أتت لقطة قريبة لوجه (إيز الك) بينت ردة فعل الفزع الذي تحقق داخل نفس (ايزيك). وفي المشـهـ الذي يجمـع بين (إيز اك) و(ماريانـا) وو الدته وهي تريـه سـاعة كانت تدخر ها لحفيدها

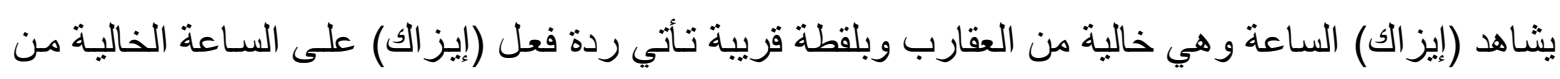

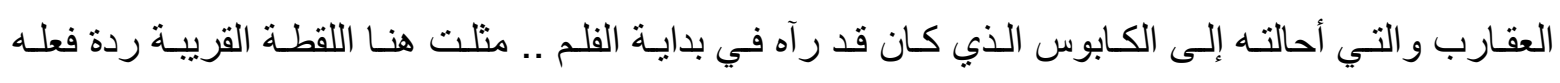
الواضحة، ترتبط الاثر السايكلوجي للشخصية. 
تنطوي قصة الفراولة (التوت البري)،حول رحلة الطبيب العجوز في ماضيه والتي تبعث مدلو لاً

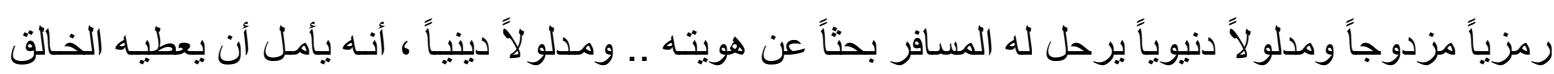

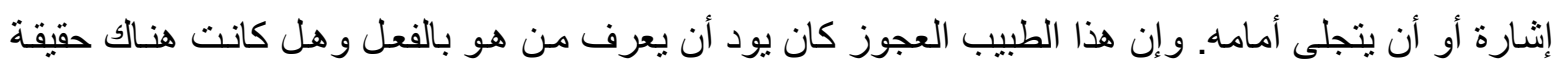

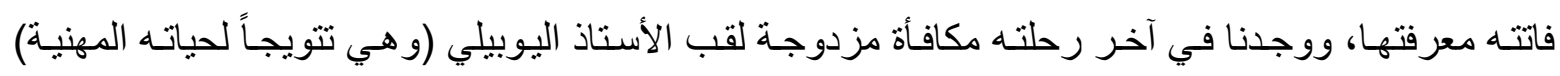
ومصالحته مع ذاته مما يضع حداً للنك و القلق الذي استحوذ عليه.

\section{|لفمل الغامسى - النتائج والاستنتاجات}

توصل الباحث إلى مجموعة من النتائج بعد تحليل عينة البحث، إذ كانت النتائج على النحو الأتي:

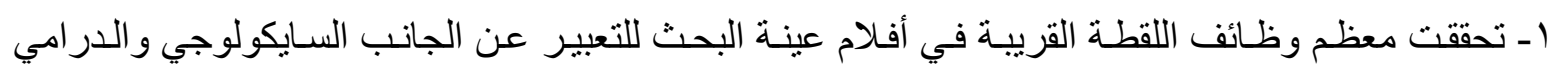
ضمن سياق الإحداث، فنجدها تعبر عن ( دواخل الثخصية، ردة الفعل،الاستجابة).

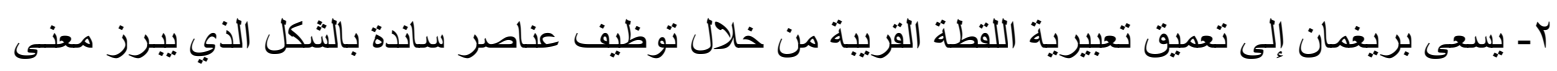
القطة بشكل مؤثر مثنلا باستخدام الإضاءة أو الموسيقى أو حركة الممثل و أحيانا من خلال التكوين.

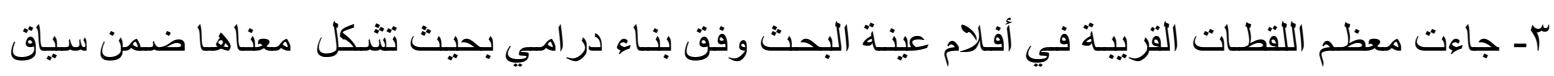
المشهد(وفي حالة رفعها تشكل خلل في تعبيرية المشهد). ع- جاءت اللقطات القريبة في أفلام بريغمان كنتيجة منطقية لطبيعة الموضو عات التي تناولها في اغلب أفلامـها.

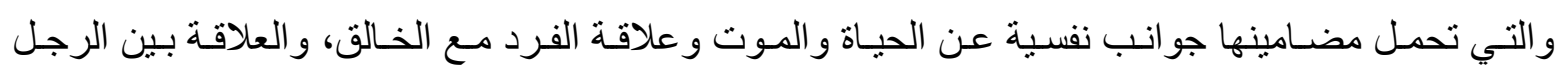
و المر أة. هـ لم تستخدم اللقطات القريبة في أفلام بريغمان بشكل مجاني لسد فر اغ ماءأو انتقال من حجم إلى أخر بل تم بناؤها ضمن النسيج الفكري للمشهد.

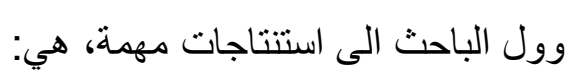

ا - يستتج الباحث: ان دقة في قر اءة تعبيرية اللقطة القريبة عند بريغمان يتطلب معرفة مسبقة بأفكار وفلسفة المخرج بريغمان. r- تميز أفلام بريغمان بأنها افلام نخبـة حيث تفتقر الى عناصر الإبهار أو التشويق التي نجدها في الأفلام التجارية وبالتالي هو لا ينطلق في معالجة أفلامه في ضو ه حسابات شباك لتذاكر.

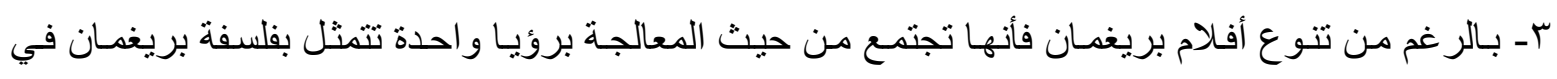
قضايا الموت و الحياة، و الحب و الوجودية. عـ تميز بريغمان بحسن التوظيف و الاختيار في توظيف اللقطة القريبة في الثكل الذي يمنحها قيمـة تعبيريـة ودر امية وسايكولوجية في بناء المشهد.

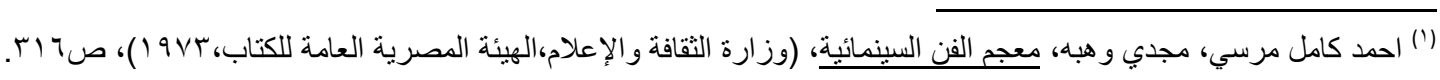

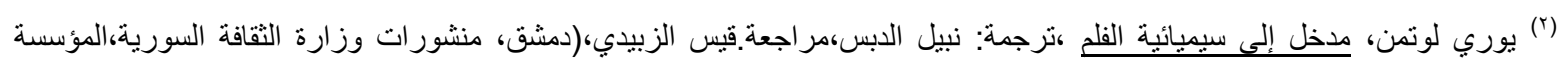

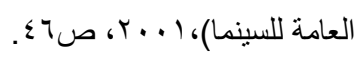


(") شارلس ج. كلارك، التصوير السينمائي للمحترفين، ترجمة: سعدعبد الرحمن قلج،(الامارات العربية المتحدة- وزارة الاعلام والثقافةـ

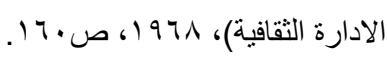

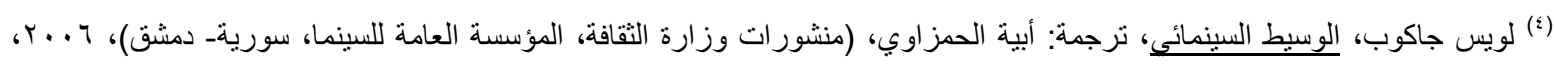

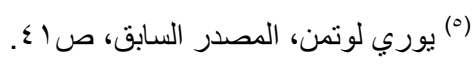

* السياق:في معجم المنجد(ساق الحديث:سرده) ويقول عنه: علاء عبد العزيز في كتابة (الفيلم بين اللغة والنص) من منشورات وزارة الثقافة

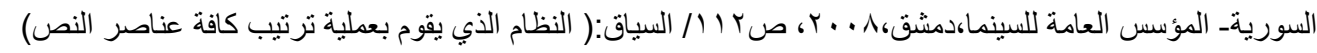

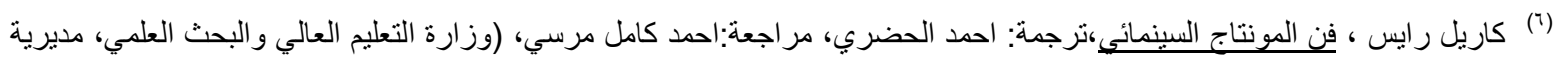

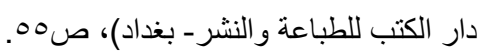

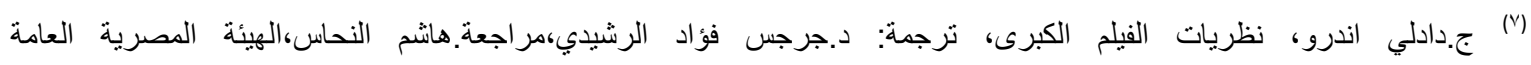

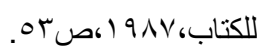

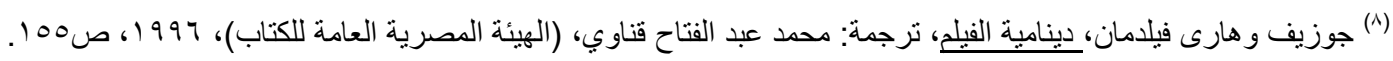

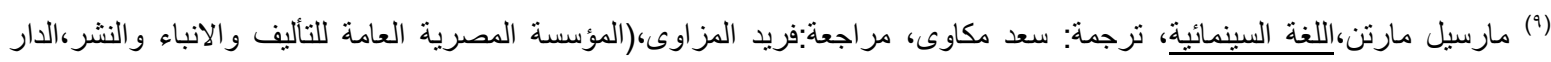

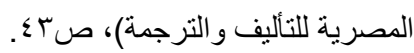

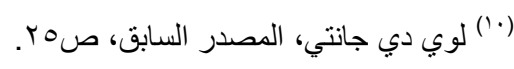

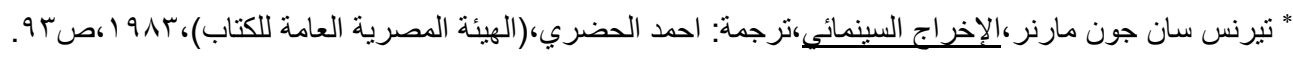

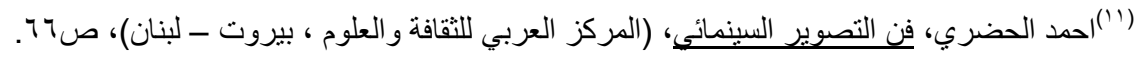

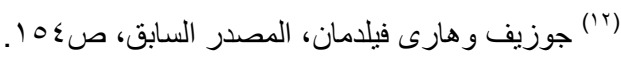

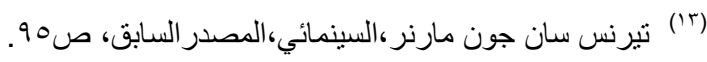

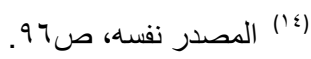

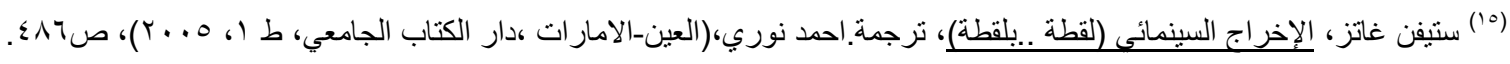

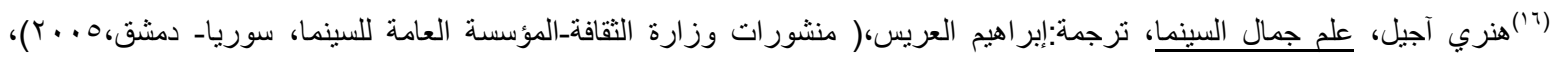

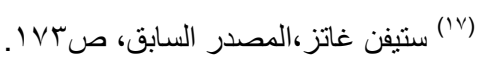

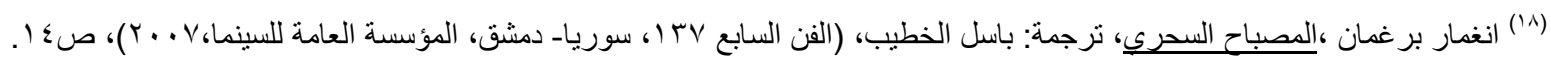

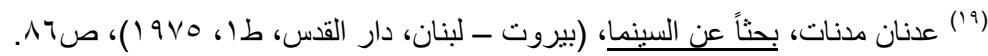

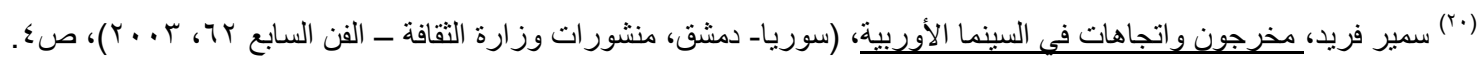

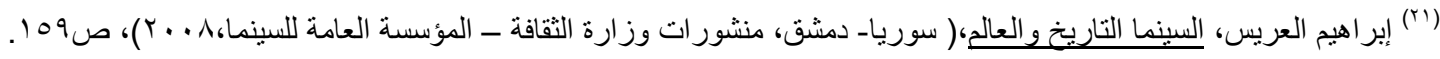

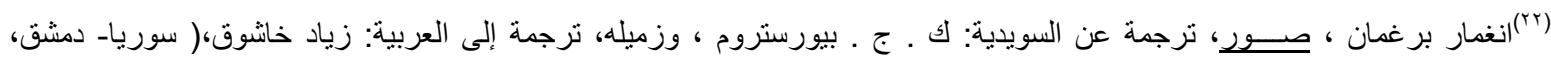

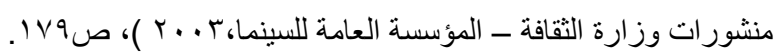

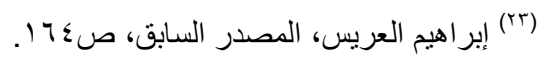

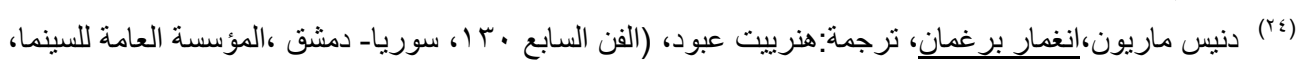

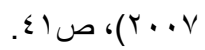
(ro)

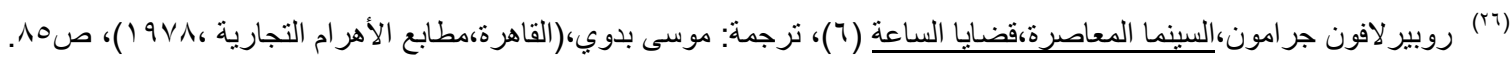

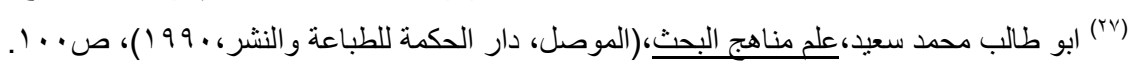

قائمة المراجع والمسادر:

ا ـ آجيل، هنري، علم جمال السينما، ترجمة، إبر اهيم العريس، منشورات وزارة الثقافة_المؤسسة العامة للسينما،سوريا- دمشق، هـ ـ. ب.

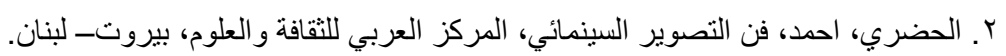

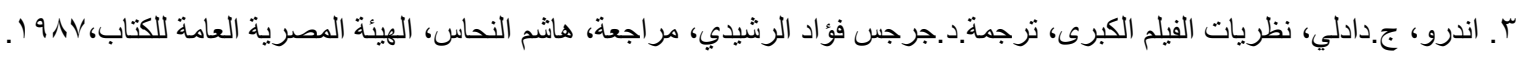


ع ـ العريس، إبر اهيم، السينماالتاريخ و العالم، سوريا- دمشق، منشور ات وزارة الثقافة- المؤسسة العامة للسينما،م . . ؟.

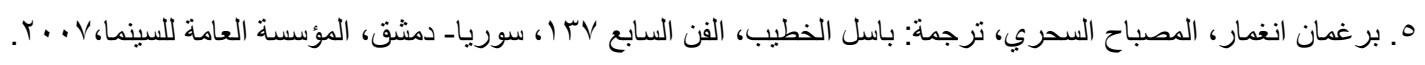

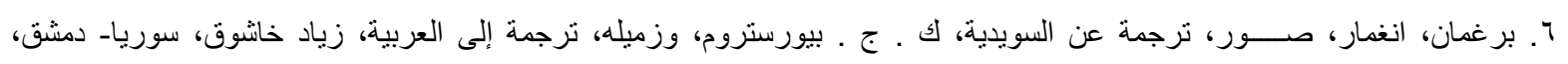

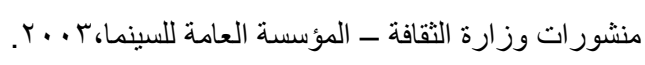

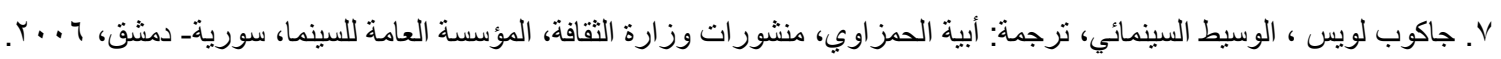

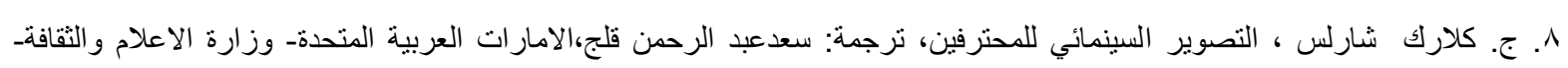

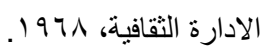

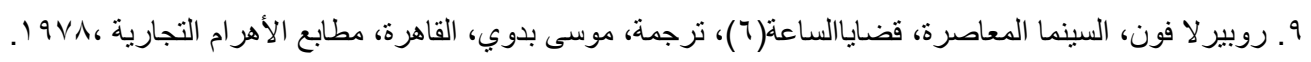

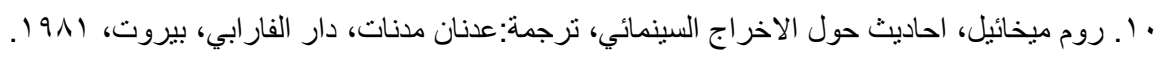

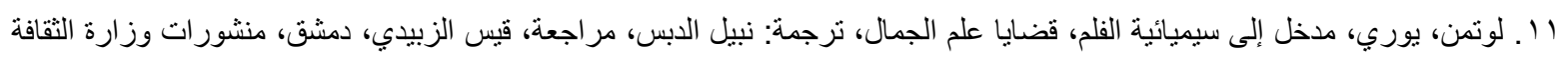

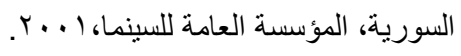

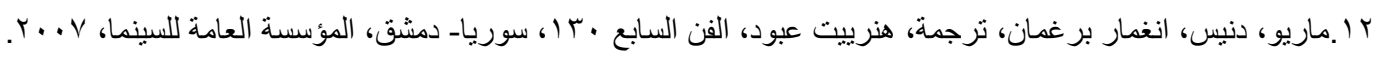

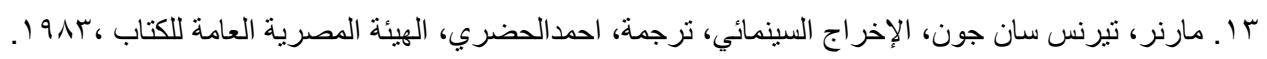

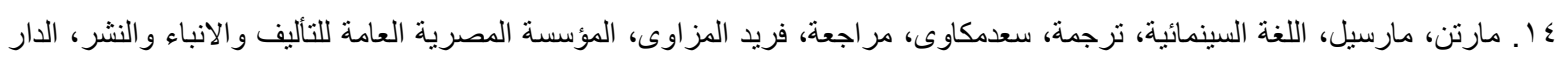
المصرية للتأليف و الترجمة (...).

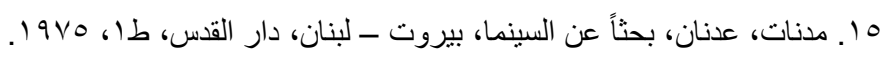

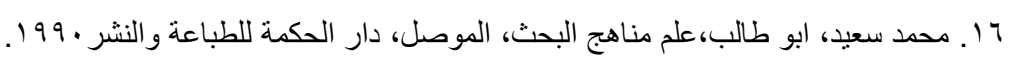

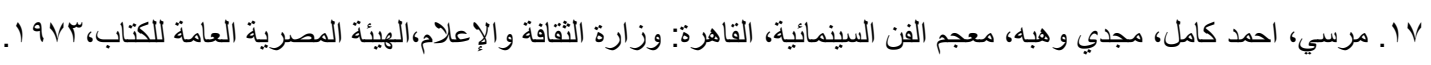

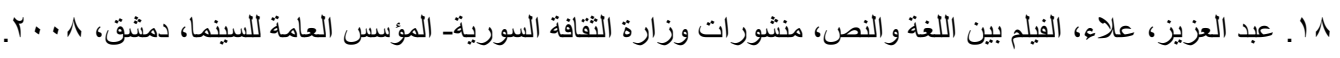

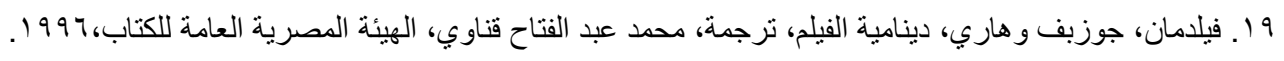

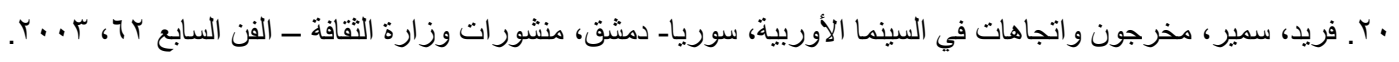

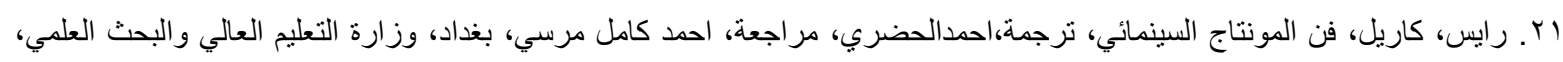
مديرية دار الكتب للطباعة و النشر(....).

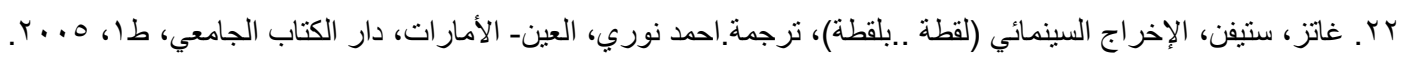

